\title{
Molecular corridors and parameterizations of volatility in the chemical evolution of organic aerosols
}

\author{
Ying $\mathbf{L i}^{1,2}$, Ulrich Pöschl ${ }^{1}$, and Manabu Shiraiwa ${ }^{1}$ \\ ${ }^{1}$ Multiphase Chemistry Department, Max Planck Institute for Chemistry, Mainz, Germany \\ ${ }^{2}$ State Key Laboratory of Atmospheric Boundary Layer Physics and Atmospheric Chemistry (LAPC), \\ Institute of Atmospheric Physics, Chinese Academy of Sciences, Beijing, China \\ Correspondence to: Manabu Shiraiwa (m.shiraiwa@mpic.de)
}

Received: 23 September 2015 - Published in Atmos. Chem. Phys. Discuss.: 15 October 2015

Revised: 1 March 2016 - Accepted: 3 March 2016 - Published: 14 March 2016

\begin{abstract}
The formation and aging of organic aerosols (OA) proceed through multiple steps of chemical reaction and mass transport in the gas and particle phases, which is challenging for the interpretation of field measurements and laboratory experiments as well as accurate representation of OA evolution in atmospheric aerosol models. Based on data from over 30000 compounds, we show that organic compounds with a wide variety of functional groups fall into molecular corridors, characterized by a tight inverse correlation between molar mass and volatility. We developed parameterizations to predict the saturation mass concentration of organic compounds containing oxygen, nitrogen, and sulfur from the elemental composition that can be measured by soft-ionization high-resolution mass spectrometry. Field measurement data from new particle formation events, biomass burning, cloud/fog processing, and indoor environments were mapped into molecular corridors to characterize the chemical nature of the observed OA components. We found that less-oxidized indoor OA are constrained to a corridor of low molar mass and high volatility, whereas highly oxygenated compounds in atmospheric water extend to high molar mass and low volatility. Among the nitrogenand sulfur-containing compounds identified in atmospheric aerosols, amines tend to exhibit low molar mass and high volatility, whereas organonitrates and organosulfates follow high $\mathrm{O}: \mathrm{C}$ corridors extending to high molar mass and low volatility. We suggest that the consideration of molar mass and molecular corridors can help to constrain volatility and particle-phase state in the modeling of OA particularly for nitrogen- and sulfur-containing compounds.
\end{abstract}

\section{Introduction}

Organic aerosols (OA) consist of a myriad of chemical species and account for a substantial mass fraction (20-90\%) of the total submicron particles in the troposphere (Jimenez et al., 2009; Nizkorodov et al., 2011). They influence regional and global climate by affecting radiative budget of the atmosphere and serving as nuclei for cloud droplets and ice crystals (Kanakidou et al., 2005). OA play a central role in air quality by causing haze formation in urban air (Huang et al., 2014; Fuzzi et al., 2015; Zhang et al., 2015) and inducing adverse health effects (Pöschl and Shiraiwa, 2015). OA are introduced into the atmosphere either by being directly emitted from fossil fuel combustion and biomass burning, or formed by multigenerational oxidation of gaseous precursors. Secondary organic aerosols (SOA) pose a wide range of volatility, hygroscopicity, and reactivity (Hallquist et al., 2009). SOA evolution is a complex process involving both chemical reaction and mass transport in the gas and particle phases (Kroll and Seinfeld, 2008; Ziemann and Atkinson, 2012; Shiraiwa et al., 2013a), but most aerosol models do not resolve multiphase processes explicitly.

Several two-dimensional (2-D) frameworks have been proposed for efficient SOA representation in chemical transport models. These 2-D frameworks were built based mainly on OA properties including volatility or (effective) saturation mass concentration, number of carbon and oxygen atoms in a molecule, mean carbon oxidation state, and atomic $\mathrm{O}: \mathrm{C}$ or $\mathrm{H}$ : C ratios (Donahue et al., 2006; Jimenez et al., 2009; Pankow and Barsanti, 2009; Heald et al., 2010; Donahue et al., 2011; Kroll et al., 2011; Cappa and Wilson, 2012; Zhang 
and Seinfeld, 2013; Wania et al., 2014, 2015). The saturation vapor pressure or pure compound saturation mass concentration $\left(C_{0}\right)$ is one of the key thermodynamic properties describing the equilibrium gas-particle partitioning of organic compounds (Pankow, 1994; Odum et al., 1996; Donahue et al., 2006; Krieger et al., 2012; Bilde et al., 2015). The effective saturation mass concentration $\left(C^{*}\right)$ includes the effect of non-ideal thermodynamic mixing with an activity coefficient $(\gamma): C^{*}=\gamma C_{0}$ (Donahue et al., 2011, 2014; Zuend and Seinfeld, 2012). The term volatility often refers to $C^{*}$ and can also be used for $C_{0}$ under the assumption of ideal thermodynamic mixing. The extent of importance of non-ideal mixing depends strongly on contents of hydrophobic and hydrophilic organic compounds, electrolytes, and water (Zuend and Seinfeld, 2012; Shiraiwa et al., 2013b).

The volatility basis set (VBS) approach uses volatility and $\mathrm{O}: \mathrm{C}$ ratio that can be constrained by chamber experiments (Donahue et al., 2006, 2011, 2012). The total organic mass is classified into volatility bins and their distribution between gas and aerosol phases is calculated according to absorptive equilibrium partitioning, assuming that gas-phase formation of semivolatile organic compounds is a limiting step of SOA formation (Pankow, 1994). VBS has been extensively applied in chemical transport models, improving prediction of organic aerosol concentrations (Lane et al., 2008; Tsimpidi et al., 2010; Shrivastava et al., 2011; Ahmadov et al., 2012; Jathar et al., 2012; Murphy et al., 2012; Matsui et al., 2014; Morino et al., 2014; Tsimpidi et al., 2014).

Saturation mass concentration is a consequence of the molecular characteristics of molar mass, chemical composition, and structure. Even though molar mass is an explicit parameter in computing absorptive SOA partitioning (Pankow, 1994; Pankow and Barsanti, 2009), the current VBS method does not account for the dependence of volatility on molar mass, assuming that the products distributed in all volatility bins have the same value of molar mass, e.g., $150 \mathrm{~g} \mathrm{~mol}^{-1}$ for anthropogenic SOA and $180 \mathrm{~g} \mathrm{~mol}^{-1}$ for biogenic SOA (Murphy and Pandis, 2009; Hayes et al., 2015). Shiraiwa et al. (2014) have shown that SOA from a variety of biogenic and anthropogenic precursors can be represented well by molecular corridors with a tight inverse correlation between molar mass $(M)$ and volatility of SOA oxidation products. The slope of these corridors corresponds to the increase in molar mass required to decrease volatility by 1 order of magnitude. Molecular corridors can help to constrain chemical and physical properties as well as reaction rates and pathways with characteristic kinetic regimes of reaction-, diffusion-, or accommodation-limited multiphase chemical kinetics involved in SOA evolution (Shiraiwa et al., 2014).

In recent years a high-resolution mass spectrometry has been employed for measurements on atmospheric aerosols, providing definitive determination of molar mass and elemental composition (Tolocka et al., 2004; Reemtsma, 2009; Williams et al., 2010; Kampf et al., 2011; Nizkorodov et al., 2011; Laskin et al., 2012; Chan et al., 2013; Hamilton et al.,
2013; Holzinger et al., 2013; Kourtchev et al., 2014). Soft ionization methods such as electrospray ionization (ESI), atmospheric pressure chemical ionization (APCI), and direct analysis in real time (DART) ionization are commonly applied for detailed molecular characterization, offering minimal fragmentation of the analytes (Nozière et al., 2015, and references therein). Such measurements have revealed that nitrogen- and sulfur-containing organic compounds are commonly present with a substantial fraction of mass in atmospheric organic aerosols. A significant amount of $\mathrm{N}-$ heterocyclic alkaloid and nitroaromatic compounds were found in biomass-burning plumes (Laskin et al., 2009; Kitanovski et al., 2012). Organonitrates have been observed to account for a substantial fraction of SOA in field and laboratory studies (Farmer et al., 2010; Rollins et al., 2012; Fry et al., 2013; Boyd et al., 2015). Organosulfates have also been detected in ambient OA (Romero and Oehme, 2005; Iinuma et al., 2007; Surratt et al., 2007, 2008; Lukács et al., 2009; Ehn et al., 2010; Schmitt-Kopplin et al., 2010; Gómez-González et al., 2012; Lin et al., 2012; Stone et al., 2012; Kahnt et al., 2013; Kundu et al., 2013; Ma et al., 2014; O'Brien et al., 2014; Staudt et al., 2014; Tao et al., 2014). Reduced sulfur-containing compounds were observed in supercooled clouds (Zhao et al., 2013) and rainwater (Mead et al., 2015).

Although nitrogen- and sulfur-containing organic compounds are important components of atmospheric aerosols, their physical properties and chemical behaviors are still poorly understood (Nozière et al., 2015) and thus are untreated in air quality models so far. In this study, we apply the molecular corridor-based approach to analyze ambient and indoor observations of organic aerosols including nitrogenand sulfur-containing organic compounds to provide insights on the physical and chemical processes driving OA evolution in the atmosphere.

\section{Characterization of 31066 organic compounds in molecular corridors}

More than 30000 organic compounds were analyzed to examine whether molecular corridors can constrain a variety of organic compounds. The used data set is the National Cancer Institute (NCI) open database (http://cactus.nci.nih.gov/ download/nci/), which contains 31066 organic compounds and corresponding SMILES codes. A list of the compounds was also provided in Wei et al. (2012). Saturation vapor pressure of each compound was estimated by the Estimation Programs Interface (EPI) Suite software (version 4.1) developed by the US Environmental Protection Agency (US EPA, 2015). The EPI Suite reports vapor pressure calculated in three separate methods, including the Antoine method (Lyman et al., 1990), the modified Grain method (Lyman, 1985), and the Mackay method (Lyman, 1985). In this study, the modified Grain estimate was used for solids and the average 
of the Antoine and the modified Grain estimates was used for liquids and gases, following the suggestions of the EPI Suite. The vapor pressure was then converted to the saturation mass concentration $\left(C_{0}\right.$ in $\left.\mu \mathrm{g} \mathrm{m}^{-3}\right)$ through the following relationship:

$C_{0}=\frac{M 10^{6} p_{0}}{760 R T}$,

where $M$ is the molar mass $\left(\mathrm{g} \mathrm{mol}^{-1}\right), p_{0}$ is the saturation vapor pressure $(\mathrm{mm} \mathrm{Hg}), R$ is the ideal gas constant $\left(8.205 \times 10^{-5}\right.$ atm K $\left.{ }^{-1} \mathrm{~mol}^{-1} \mathrm{~m}^{3}\right)$, and $T$ is the temperature (K).

We classified these organic compounds into six classes based on chemical composition: $\mathrm{CH}, \mathrm{CHO}, \mathrm{CHN}, \mathrm{CHON}$, CHOS, and CHONS, with the number of compounds of 328 , $8420,2968,13628,925$, and 3367, respectively. These compounds cover a molar mass from 41 to $1779 \mathrm{~g} \mathrm{~mol}^{-1}$. In total we consider 22 structural sub-classes including N-containing compounds of amine (primary, secondary, tertiary, and quaternary), amide, azo, azide, amino acid, imine, nitroso, nitro, alkyl nitrite, nitrile, and organonitrate as well as S-containing compounds of organosulfate, sulfonate, sulfone, sulfoxide, sulfite, heterocyclic ring, thioate, and thiocarbamate.

Figure 1 shows that most of the organic compounds (small markers color-coded by atomic $\mathrm{O}: \mathrm{C}$ ratio) fall into the molecular corridor with upper and lower boundaries represented by linear alkanes $\left(\mathrm{C}_{n} \mathrm{H}_{2 n+2}, \mathrm{O}: \mathrm{C}=0\right.$; purple dashed line) and sugar alcohols $\left(\mathrm{C}_{n} \mathrm{H}_{2 n+2} \mathrm{O}_{n}, \mathrm{O}: \mathrm{C}=1\right.$; red dashed line), respectively. It indicates that the 2-D space of molar mass and saturation mass concentration can constrain most of the organics, including compounds containing heteroatoms of $\mathrm{N}$ and S. About 1000 compounds with branched structures lie above the linear alkane line among the $\mathrm{CHO}$ class (Fig. 1b), as volatilities of branched compounds are higher than those of compounds with linear structures. The surrogate compounds with the mean values of $M, C_{0}$, and $\mathrm{O}: \mathrm{C}$ ratio computed for each of the structural sub-classes are indicated by larger symbols with error bars indicating standard deviations. Figure 1c shows clearly that mean values of $C_{0}$ decrease as more hydrogen atoms of an ammonia structure are replaced by alkyl or aryl groups, forming the primary, secondary, tertiary and quaternary amine. Figure 1d-f show that the molar mass of $\mathrm{CHON}, \mathrm{CHOS}$, and CHONS can be up to $1000 \mathrm{~g} \mathrm{~mol}^{-1}$ and $C_{0}$ can be as low as $10^{-30} \mu \mathrm{g} \mathrm{m}^{-3}$. The compounds with high $\mathrm{O}: \mathrm{C}$ ratios are organosulfate and sulfite (the mean $\mathrm{O}: \mathrm{C}$ of $\sim 1$ ), followed by compounds in subclasses of sulfonate, sulfone, sulfoxide, organonitrate, nitro, alkyl nitrites, nitroso, or amino acid, which tend to occupy the space close to the sugar alcohol line.

OA can be classified as (1) volatile organic compounds (VOC; $C_{0}>3 \times 10^{6} \mu \mathrm{g} \mathrm{m}^{-3}$ ), (2) intermediate volatility OC (IVOC; $300<C_{0}<3 \times 10^{6} \mu \mathrm{g} \mathrm{m}^{-3}$ ), (3) semivolatile OC (SVOC; $0.3<C_{0}<300 \mu \mathrm{g} \mathrm{m}^{-3}$ ), (4) low-volatile OC (LVOC; $3 \times 10^{-4}<C_{0}<0.3 \mu \mathrm{g} \mathrm{m}^{-3}$ ), and (5) extremely low-volatile OC (ELVOC; $C_{0}<3 \times 10^{-4} \mu \mathrm{g} \mathrm{m}^{-3}$ ) (Donahue et al., 2011; Murphy et al., 2014). Figure 2 shows the relationship between saturation mass concentration and molar mass derived from these 30000 compounds. The molar mass of VOC is usually less than $160 \mathrm{~g} \mathrm{~mol}^{-1}, 130-250 \mathrm{~g} \mathrm{~mol}^{-1}$ for IVOC, $180-330 \mathrm{~g} \mathrm{~mol}^{-1}$ for SVOC, 210-400 $\mathrm{g} \mathrm{mol}^{-1}$ for LVOC, and larger than $260 \mathrm{~g} \mathrm{~mol}^{-1}$ for ELVOC. As the volatility decreases, the covered molar mass range becomes wider, indicating more compounds are encompassed with increasing complexity. Meanwhile, the volatility decreases as the average molar mass of every composition group increases. For example, the average molar mass of the $\mathrm{CHO}$ class in the VOC group is $117 \mathrm{~g} \mathrm{~mol}^{-1}$, which increases to $471 \mathrm{~g} \mathrm{~mol}^{-1}$ in the ELVOC group. The symbol sizes are scaled with relative abundance of compounds in each composition class. Many of the $\mathrm{CH}$ compounds $(\sim 69 \%)$ are distributed in the VOC and IVOC groups. Of the $\mathrm{CHO}$ and $\mathrm{CHN}$ compounds, $70 \%$ are populated in the IVOC and SVOC groups. More than $80 \%$ of the $\mathrm{CHON}$ and $\mathrm{CHOS}$ compounds are located in the range covered from IVOC to LVOC, and about $10 \%$ of them belong to the ELVOC group. Of the CHONS compounds, $90 \%$ cover the range from SVOC to ELVOC. Given that the molar mass is observationally constrained, it is suitable to use the molar mass to constrain the volatility of organic compounds.

\section{Parameterization of saturation mass concentration by elemental composition}

Accurate prediction of volatility requires structural information of the organic compounds, which is often difficult to obtain from field measurements. We predict $C_{0}$ as a function of elemental composition that is often determined by soft-ionization high-resolution mass spectrometry. Donahue et al. (2011) have developed a parameterization to estimate $C_{0}$ as $\log _{10} C_{0}=f\left(n_{\mathrm{C}}, n_{\mathrm{O}}\right)$ for the $\mathrm{CHO}$ compounds. We broaden this formulation to $\log _{10} C_{0}=f\left(n_{\mathrm{C}}, n_{\mathrm{O}}, n_{\mathrm{N}}, n_{\mathrm{S}}\right)$ to be applicable to the $\mathrm{N}$ - and $\mathrm{S}$-containing compounds:

$$
\begin{aligned}
\log _{10} C_{0}= & \left(n_{\mathrm{C}}^{0}-n_{\mathrm{C}}\right) b_{\mathrm{C}}-n_{\mathrm{O}} b_{\mathrm{O}}-2 \frac{n_{\mathrm{C}} n_{\mathrm{O}}}{n_{\mathrm{C}}+n_{\mathrm{O}}} b_{\mathrm{CO}} \\
& -n_{\mathrm{N}} b_{\mathrm{N}}-n_{\mathrm{S}} b_{\mathrm{S}},
\end{aligned}
$$

where $n_{\mathrm{C}}^{0}$ is the reference carbon number; $n_{\mathrm{C}}, n_{\mathrm{O}}, n_{\mathrm{N}}$, and $n_{\mathrm{S}}$ denote the numbers of carbon, oxygen, nitrogen, and sulfur atoms, respectively; $b_{\mathrm{C}}, b_{\mathrm{O}}, b_{\mathrm{N}}$, and $b_{\mathrm{S}}$ denote the contribution of each atom to $\log _{10} C_{0}$, respectively, and $b_{\mathrm{CO}}$ is the carbon-oxygen nonideality (Donahue et al., 2011). Values of $b$ coefficients were obtained by fitting with multi-linear least squares analysis to the 30000 compounds for each class $(\mathrm{CH}$, $\mathrm{CHO}, \mathrm{CHN}, \mathrm{CHON}, \mathrm{CHOS}$, and CHONS). The best-fit parameters obtained at $298 \mathrm{~K}$ in this analysis are presented in Table 1. The nonlinear terms of nitrogen-oxygen and sulfuroxygen are not considered, as they impact the predicting results only slightly. Considering the number of hydrogen atoms in Eq. (2) could improve the prediction for compounds 
(a) $\mathrm{CH}(328)$

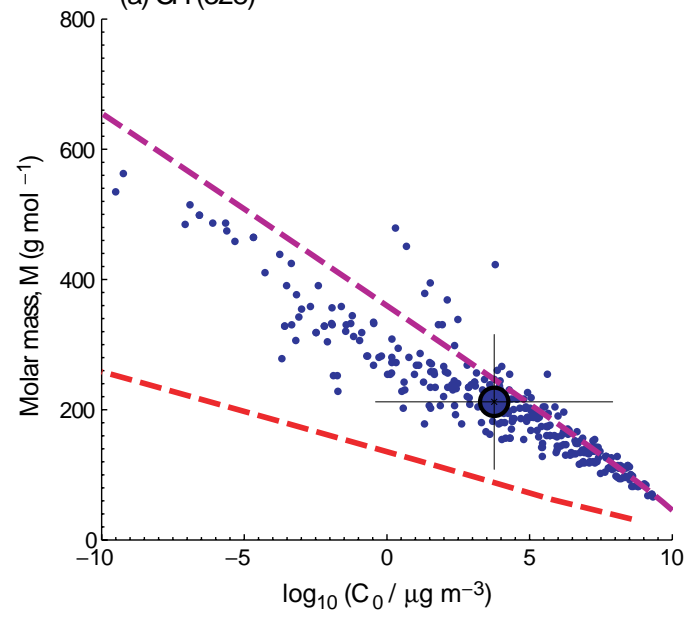

(c) $\mathrm{CHN}(2968)$

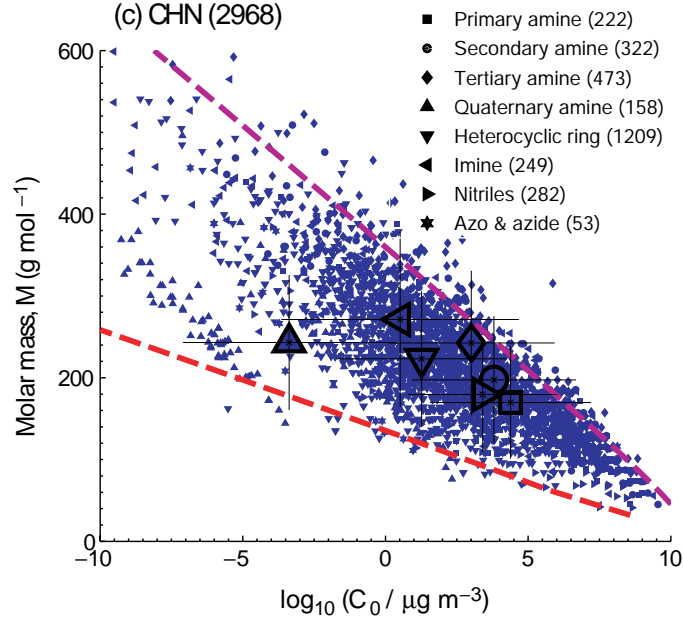

(b) $\mathrm{CHO}(8420)$

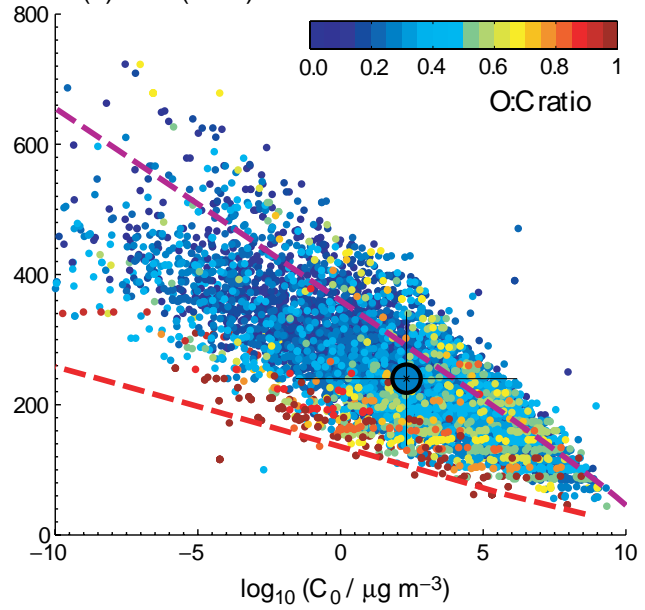

(d) $\mathrm{CHON}(13628) \quad$ : Amide (5117)
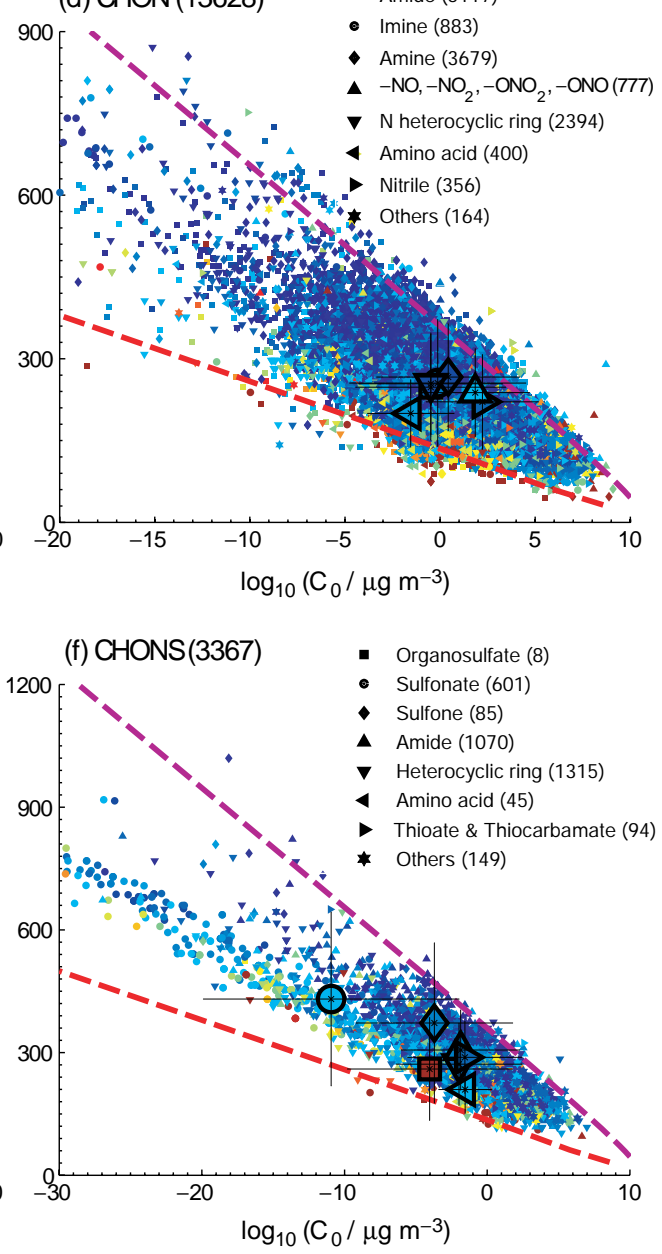

Figure 1. Molecular corridors of molar mass $(M)$ vs. saturation mass concentration $\left(C_{0}\right)$ for organic compounds in elemental composition classes of (a) $\mathrm{CH}$, (b) $\mathrm{CHO}$, (c) $\mathrm{CHN}$, (d) $\mathrm{CHON}$, (e) $\mathrm{CHOS}$, and (f) CHONS. The data comprise 31066 compounds from the NCI open database. The dotted lines represent linear alkanes $\mathrm{C}_{n} \mathrm{H}_{2 n+2}$ (purple with $\mathrm{O}: \mathrm{C}=0$ ) and sugar alcohols $\mathrm{C}_{n} \mathrm{H}_{2 n+2} \mathrm{O}_{n}$ (red with $\mathrm{O}: \mathrm{C}=1$ ). The small markers correspond to individual compounds identified in each structural sub-class (see Sect. 2), color-coded by atomic O:C ratio. The larger symbols indicate the surrogate compounds with the mean values of $M, C_{0}$, and $\mathrm{O}: \mathrm{C}$ ratio computed for each of the structural sub-classes with error bars indicating standard deviations. Note that the data points above the linear alkane line in (b) represent molecules with branched structures. 


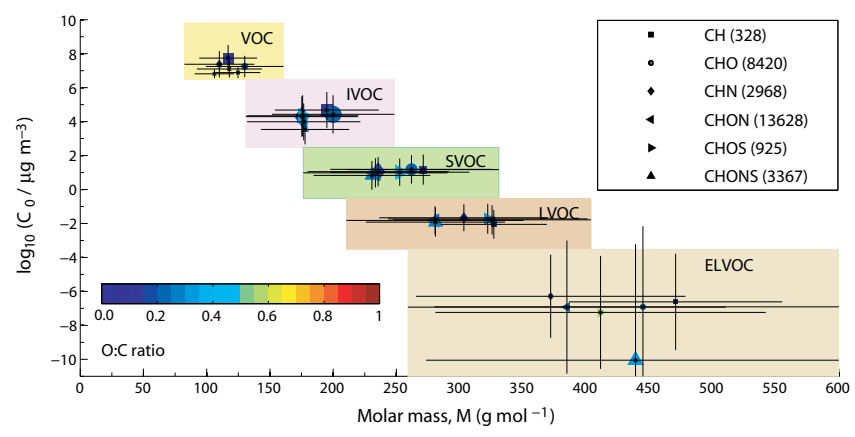

Figure 2. Average molar mass $(M)$, saturation mass concentration $\left(C_{0}\right)$, and $\mathrm{O}: \mathrm{C}$ ratio for organic compounds from the $\mathrm{NCI}$ database categorized by elemental composition $(\mathrm{CH}, \mathrm{CHO}, \mathrm{CHN}$, CHON, CHOS, CHONS) and volatility (VOC, IVOC, SVOC, LVOC, ELVOC). The data points and error bars represent arithmetic mean values and standard deviations for each class of elemental composition. The symbol sizes are scaled by the number of compounds in each class. The center and borders of the colored boxes represent the mean and standard deviations of all compounds included in each volatility class.

in the $\mathrm{CH}$ class slightly, but they have little impact on the prediction for compounds in other composition classes. Detailed information including an estimated $b_{\mathrm{H}}$ (the contribution of hydrogen atoms to $\log _{10} C_{0}$ ) can be found in the Supplement. As the effect of inclusion of hydrogen is limited, further analysis was conducted using Eq. (2) for simplicity.

The temperature dependence of $C_{0}$ can be approximated by an Arrhenius-type equation resembling the ClausiusClapeyron equation (Donahue et al., 2006; Cappa and Jimenez, 2010):

$C_{0}(T)=C_{0}\left(T_{\text {ref }}\right)\left(\frac{T_{\text {ref }}}{T}\right) \exp \left[-\frac{\Delta H_{\text {vap }}}{R}\left(\frac{1}{T}-\frac{1}{T_{\text {ref }}}\right)\right]$,

where $T_{\text {ref }}$ is the temperature at a reference state $(298 \mathrm{~K}$ in this study). The enthalpy of vaporization $\Delta H_{\mathrm{vap}}\left(\mathrm{kJ} \mathrm{mol}^{-1}\right)$ could be estimated by $C_{0}$, as there is a nearly linear relationship between $\log _{10} C_{0}(300 \mathrm{~K})$ and $\Delta H_{\text {vap }}$ (Epstein et al., 2010).

The developed estimation method was compared with the EPI Suite for the 30000 compounds as shown in Fig. 3 and Table S2. The agreement between the two methods was assessed by statistical measures of correlation coefficient $(R)$, mean absolute gross error (MAGE), and mean bias (MB). As shown in Fig. 3, our new method performs well with $R$ above 0.8 and MAGE below 1.8 for all the composition classes. In the CHN class, our method performs well for primary, secondary, and tertiary amines, heterocyclic rings, imines, and nitriles (Table S2). Our method overestimates $C_{0}$ of the quaternary amine located in LVOC and ELVOC ranges. For the CHON class, relatively large errors are found for quaternary amine and amino acid. Note that there are relatively few data for organonitrate. When nitrate functionality appears in the amine, they are assigned to the amine class. Nitroso and
Table 1. Composition classes and the $n_{\mathrm{C}}^{0}$ and $b$ values for saturation mass concentration parameterizations obtained by least-squares optimization using the NCI database.

\begin{tabular}{lrrrrrr}
\hline Classes & $n_{\mathrm{C}}^{0}$ & $b_{\mathrm{C}}$ & $b_{\mathrm{O}}$ & $b_{\mathrm{CO}}$ & $b_{\mathrm{N}}$ & $b_{\mathrm{S}}$ \\
\hline CH & 23.80 & 0.4861 & & & & \\
CHO & 22.66 & 0.4481 & 1.656 & -0.7790 & & \\
CHN & 24.59 & 0.4066 & & & 0.9619 & \\
CHON & 24.13 & 0.3667 & 0.7732 & -0.07790 & 1.114 & \\
CHOS & 24.06 & 0.3637 & 1.327 & -0.3988 & & 0.7579 \\
CHONS & 28.50 & 0.3848 & 1.011 & 0.2921 & 1.053 & 1.316 \\
\hline
\end{tabular}

alkyl nitrite are treated similarly. For structural classes in the CHOS and CHONS, our method works well with $R>0.82$.

Our method was also tested with a different set of organic compounds and a different estimation method. We used 704 SOA oxidation products of $\mathrm{CHO}$ compounds (Shiraiwa et al., 2014) with saturation vapor pressure estimated using the EVAPORATION model (Compernolle et al., 2011). As shown in Fig. 4a, our newly developed parameterization also agrees well with EVAPORATION predictions, showing better agreement than Donahue et al. (2011), as indicated by smaller values of MB and MAGE. Figure $4 b$ shows the comparison between $C_{0}$ estimated by our parameterization and the experimental data. The experimental $C_{0}$ values of 1729 organic compounds with heteroatoms including $\mathrm{N}$ or $\mathrm{S}$ are taken from the PHYSPROP database that is part of the EPI Suite (http://www.srcinc.com/what-we-do/ environmental/scientific-databases.html). Our method gives a good performance with $R$ of 0.84 , MB of -0.41 , and MAGE of 1.24.

As shown in Fig. 4b, the estimation error increases as the saturation mass concentration decreases. An accurate prediction of low vapor pressure is difficult due, in large part, to the limitation caused by measurement challenges. For example, the measured vapor pressure of dicarboxylic acid, a low-volatility compound commonly found in atmospheric aerosols, disagreed by up to 2 orders of magnitude between different measurement techniques (Krieger et al., 2012; Huisman et al., 2013; Bilde et al., 2015). The effects of functionalization, phase states (crystalline, amorphous, (subcooled) liquid), and molecular structure need to be considered in future experimental studies (Huisman et al., 2013; Bilde et al., 2015). The vapor pressure estimation methods could give very divergent predictions for the same compound (Clegg et al., 2008; O'Meara et al., 2014). Another difficulty in predicting low vapor pressure is that most estimation methods, including the EPI Suite, are constrained by databases heavily biased toward mono-functional compounds with saturation vapor pressures in the range of $\sim 10^{3}-10^{5} \mathrm{~Pa}$ (Barley and McFiggans, 2010; Krieger et al., 2012). The EPI Suite uses the PHYSPROP database as its training data set. When comparing with the PHYSPROP database, the estimation error of EPI Suite increases as the vapor pressure decreases, 

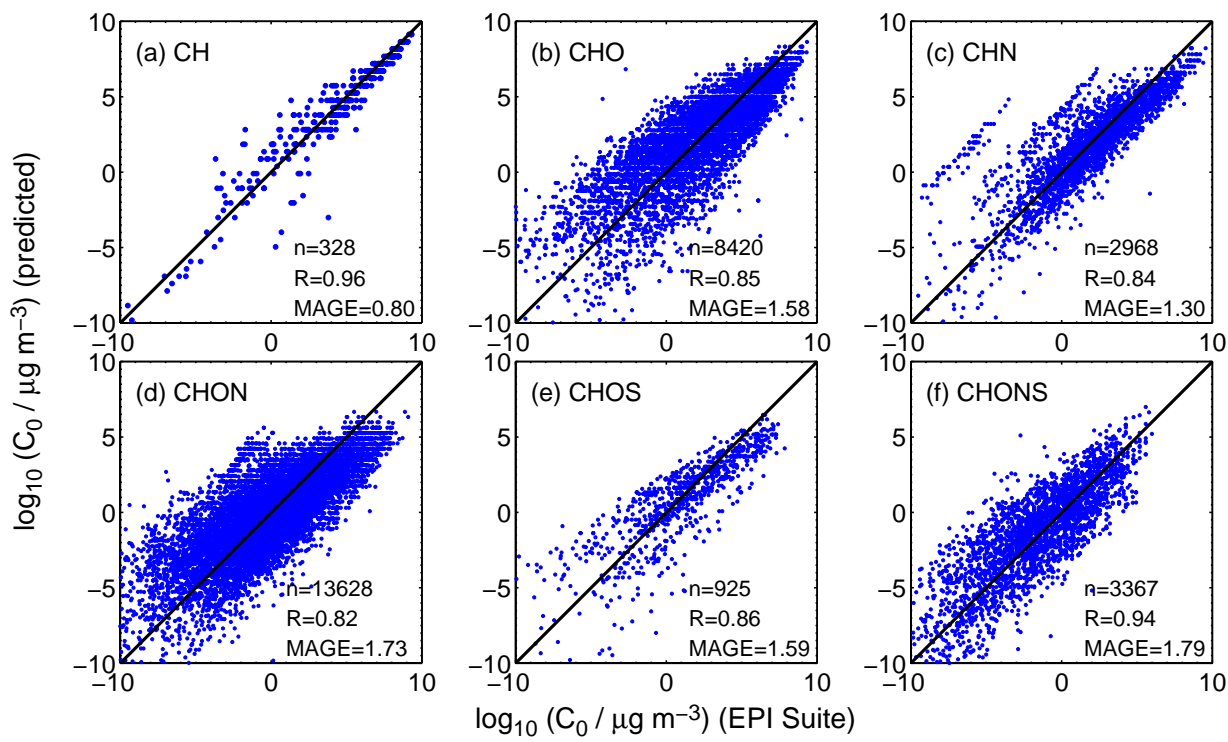

Figure 3. Saturation mass concentration $\left(C_{0}\right)$ of organic compounds predicted by Eq. (2) from this study plotted against $C_{0}$ determined by the EPI Suite software in the NCI database for elemental composition classes of (a) $\mathrm{CH},(\mathbf{b}) \mathrm{CHO}$, (c) $\mathrm{CHN}$, (d) $\mathrm{CHON}$, (e) CHOS, and (f) CHONS.
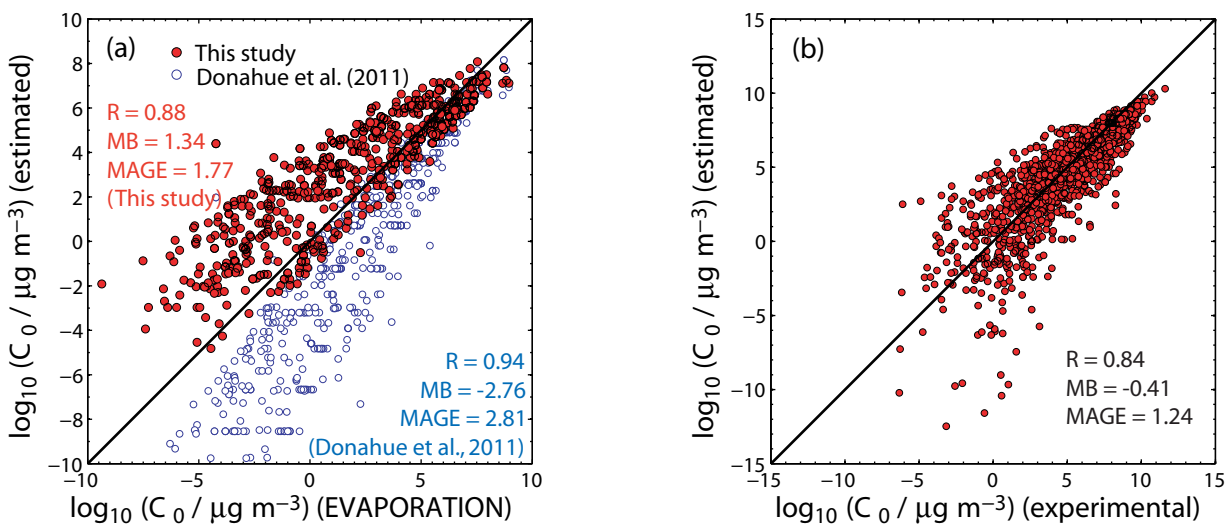

Figure 4. (a) Saturation mass concentration $\left(C_{0}\right)$ of $\mathrm{CHO}$ compounds predicted by Eq. (2) with the coefficients from this study and with the coefficients from Donahue et al. (2011) plotted against $C_{0}$ computed by the EVAPORATION model (Compernolle et al., 2011). The data comprise 704 SOA oxidation products from biogenic (isoprene, $\alpha$-pinene, limonene, glyoxal) and anthropogenic precursors (C12 alkanes) as presented in Shiraiwa et al. (2014). (b) Comparison of $C_{0}$ predicted by Eq. (2) in this study and experimental values taken from PHYSPROP Database (http://www.srcinc.com/what-we-do/environmental/scientific-databases.html).

especially when the vapor pressure decreases below $10^{-4} \mathrm{~Pa}$ (http://www.epa.gov/sab/pdf/sab-07-011.pdf).

Despite of some limitations as described above, the new estimation parameterization derived from a large data set in this study is sufficiently good to predict $C_{0}$ for various structural organic classes as shown by overall good correlation. In the next section, the saturation mass concentration of ambient OA (e.g., the compounds with elemental composition measured by high-resolution mass spectrometry techniques) is estimated using Eq. (2).

\section{Application of molecular corridors to atmospheric aerosols}

Applying the newly developed saturation mass concentration estimation method to laboratory experiments and field campaigns, the observed organic compounds were mapped into the molecular corridor with an alternative representation displaying $C_{0}$ as a function of molar mass, which appears more straightforward for direct comparisons to mass spectra (Shiraiwa et al., 2014). The used observation data set is summarized in Table 2. In total, 9053 organic compounds were collected from chamber experiments for new particle forma- 
Table 2. Summary of the number of organic compounds in the composition classes (CH, CHO, CHN, CHON, CHOS, and CHONS) measured in 11 observation events.

\begin{tabular}{|c|c|c|c|c|c|c|c|c|}
\hline Observations & $\mathrm{CH}$ & $\mathrm{CHO}$ & $\mathrm{CHN}$ & CHON & $\mathrm{CHOS}$ & CHONS & Total & References \\
\hline \multicolumn{9}{|c|}{ Experiments } \\
\hline New particle formation & & 55 & & & & & 55 & $\begin{array}{l}\text { Ehn et al. }(2012)^{\mathrm{a}} \text {, } \\
\text { Schobesberger et al. (2013) }\end{array}$ \\
\hline \multicolumn{9}{|c|}{ Field } \\
\hline Forest & 1 & 37 & 23 & 4 & 1 & & 66 & Ehn et al. $(2010,2012)^{\mathrm{a}}$ \\
\hline Biomass burning & & & 13 & 36 & & 2 & 51 & Laskin et al. $(2009)^{\mathrm{b}}$ \\
\hline Urban & & & & & 212 & 37 & 249 & $\begin{array}{l}\text { Lin et al. }(2012)^{\mathrm{b}} \text {, } \\
\text { Stone et al. }(2012)^{\mathrm{b}} \text {, } \\
\text { Ma et al. }(2014)^{\mathrm{b}} \text {, } \\
\text { O'Brien et al. }(2014)^{\mathrm{b}} \text {, } \\
\text { Tao et al. }(2014)^{\mathrm{b}}\end{array}$ \\
\hline Mt. Sonnblick & 33 & 211 & 47 & 271 & 37 & 31 & 630 & Holzinger et al. $(2010)^{\mathfrak{c}}$ \\
\hline Fog & & 1425 & & 711 & 218 & 83 & 2437 & Mazzoleni et al. (2010) b \\
\hline Cloud & & 1055 & & 1985 & 357 & 544 & 3941 & Zhao et al. $(2013)^{\mathrm{b}}$ \\
\hline Rain in New Jersey & & 192 & 6 & 320 & 129 & 52 & 699 & Altieri et al. $(2009 \mathrm{a}, \mathrm{b})^{\mathrm{b}}$ \\
\hline Rain in Bermuda & & & 50 & 734 & & 27 & 811 & Altieri et al. $(2012)^{\mathrm{b}}$ \\
\hline \multicolumn{9}{|c|}{ Indoor } \\
\hline Reactions of skin lipids and $\mathrm{O}_{3}$ & 1 & 25 & & & & & 26 & $\begin{array}{l}\text { Wisthaler and } \\
\text { Weschler }(2010)^{\mathrm{c}}\end{array}$ \\
\hline Tobacco smoke & 20 & 42 & 13 & 13 & & & 88 & Sleiman et al. $(2010 a, b)^{d}$ \\
\hline
\end{tabular}

Applied analytical methods: ${ }^{\text {a }}$ atmospheric pressure interface time-of-flight mass spectrometry (APi-TOF-MS); ${ }^{b}$ electrospray ionization mass spectrometry (ESI-MS);

${ }^{\mathrm{c}}$ proton-transfer-reaction mass-spectrometer (PTR-MS); ${ }^{\mathrm{d}}$ gas chromatography mass spectrometry (GC-MS).

tion (Ehn et al., 2012; Schobesberger et al., 2013) and field measurements at a boreal forest (Ehn et al., 2010, 2012), at a mountain site (Holzinger et al., 2010), in urban areas (Lin et al., 2012; Stone et al., 2012; Ma et al., 2014; O'Brien et al., 2014; Tao et al., 2014), in biomass-burning plumes (Laskin et al., 2009), in radiation fog (Mazzoleni et al., 2010), in supercooled cloud (Zhao et al., 2013), and in rain (Altieri et al., 2009a, b, 2012), as well as indoor measurements of OA originated from tobacco smoke (Sleiman et al., 2010a, b) and human skin lipids (Wisthaler and Weschler, 2010). The organic compounds were categorized into $\mathrm{CH}$ (55), CHO (3042), CHN (152), CHON (4074), CHOS (954), and CHONS (776) classes. These large data sets provide insights into the chemical and physical nature of OA from different sources and their evolution upon chemical transformation.

\subsection{CH and CHO compounds}

Figure 5 shows the $\mathrm{CH}$ and $\mathrm{CHO}$ compounds measured in different atmospheric conditions plotted in molecular corridors. The small markers show individual observed compounds color-coded by atomic $\mathrm{O}: \mathrm{C}$ ratio. The larger symbols with error bars represent mean values of molar mass, saturation mass concentration, and $\mathrm{O}: \mathrm{C}$ ratio derived from every observation event. Figure 5a shows abundant organic compounds found in new particle formation (NPF) experiments performed at the Cosmics Leaving Outdoor Droplets (CLOUD) chamber at CERN (Schobesberger et al., 2013) and the Jülich Plant Atmosphere Chamber (Mentel et al., 2009; Ehn et al., 2012). The values of $\mathrm{O}: \mathrm{C}$ ratio are all above 0.3 and some organic compounds are remarkably highly oxidized ( $\mathrm{O}: \mathrm{C}$ up to 1.4). The compounds cover the mass range of $184-558 \mathrm{~g} \mathrm{~mol}^{-1}$ in the volatility range of IVOC-ELVOC, spreading in a large space of the molecular corridor. These oxidized organic compounds play an important role in formation and growth of OA particles in ambient conditions (Ehn et al., 2012; Riipinen et al., 2012; Kulmala et al., 2013; Schobesberger et al., 2013; Ehn et al., 2014; Riccobono et al., 2014; Wildt et al., 2014).

Figure $5 \mathrm{~b}$ shows highly oxidized compounds observed at the boreal forest research station in Hyytiälä, Finland, during NPF events (Ehn et al., 2010, 2012). The average O:C ratio is as high as 1.1. The locations of organic compounds observed in the CLOUD experiments (Fig. 5a) and at Hyytiälä (Fig. 5b) in the molecular corridor are similar by occupying the space close to the sugar alcohol line (high $\mathrm{O}: \mathrm{C}$ corridor; Shiraiwa et al., 2014), indicating that chemical properties of these organic compounds are similar and chamber experiments represent ambient observations well. Such lowvolatility and highly oxygenated compounds may be gener- 

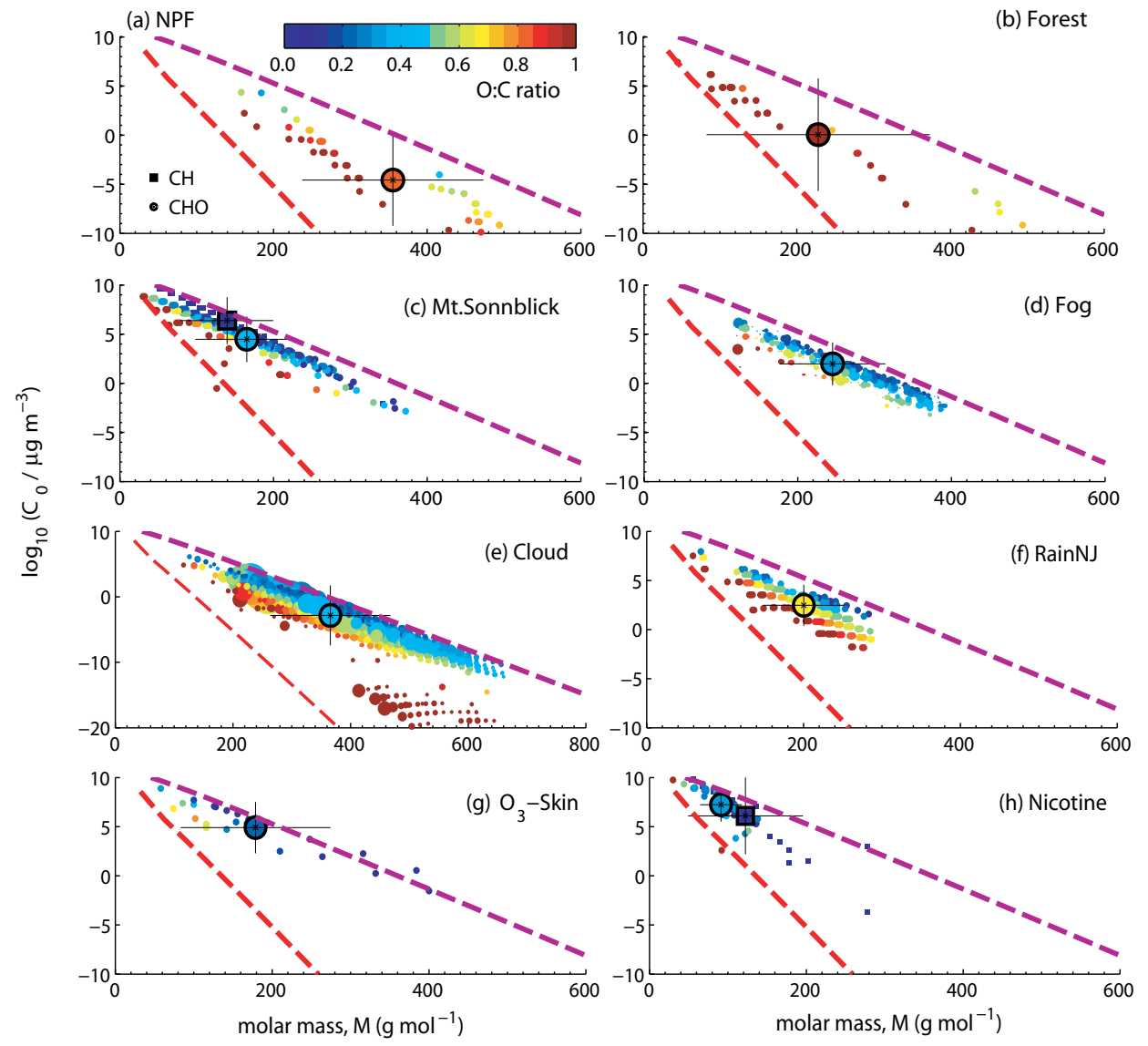

Figure 5. Molecular corridors of saturation mass concentration $\left(C_{0}\right)$ vs. molar mass $(M)$ for $\mathrm{CH}$ and $\mathrm{CHO}$ compounds measured in (a) chamber experiments for new particle formation (Ehn et al., 2012; Schobesberger et al., 2013), (b) field campaigns conducted in the boreal forest of Hyytiälä (Ehn et al., 2010, 2012), (c) a field campaign conducted at Mt. Sonnblick (Holzinger et al., 2010), and measurements of (d) fog in the city of Fresno (Mazzoleni et al., 2010), (e) clouds at Mt. Werner (Zhao et al., 2013), (f) rain in New Jersey (Altieri et al., 2009a, b), (g) indoor aerosols from human skin lipids and ozone (Wisthaler and Weschler, 2010), and (h) tobacco smoke (Sleiman et al., 2010a, b). The small markers represent individual compounds identified in each data set color-coded by atomic $\mathrm{O}: \mathrm{C}$ ratio. The size of the small markers in (d) and (e) is linearly scaled by relative intensity of MS signal. The larger symbols with error bars indicate surrogate compounds with the mean values of $M, C_{0}$, and $\mathrm{O}: \mathrm{C}$ ratio computed for each data set.

ated by autoxidation reactions (Crounse et al., 2013; Ehn et al., 2014; Mentel et al., 2015).

Figure 5c shows organic compounds observed in the remote area at Mt. Sonnblick, Austria (Holzinger et al., 2010). The observed compounds were less oxidized and lie close to the alkane line. Aqueous-phase processing of organic compounds leads to formation of highly oxidized compounds in fog (Fig. 5d; Mazzoleni et al., 2010), cloud (Fig. 5e; Zhao et al., 2013), and rain (Fig. 5f; Altieri et al., 2009a, b, 2012), suggesting that atmospheric water is enriched in polar compounds compared to atmospheric particulate matter. Higher oxidized compounds tend to have lower molar mass than less-oxidized compounds, indicating that fragmentation is an important pathway in aqueous-phase oxidation (Sun et al., 2010; McNeill et al., 2012; Carlton and Turpin, 2013; Daumit et al., 2014; Ervens, 2015). In addition, aqueous processing can produce high molar mass and high $\mathrm{O}: \mathrm{C}$ com- pounds through oligomerization (Altieri et al., 2008; Lim et al., 2010; Ervens et al., 2011), as seen in super-cooled cloud water collected at a remote site on Mt. Werner in the USA in Fig. 5e.

Figure $5 \mathrm{~g}$ shows the oxidation products from reactions of ozone and human skin lipids (Wisthaler and Weschler, 2010). The majority of products are VOC and IVOC with $\mathrm{O}: \mathrm{C}<0.7$ and molar mass $<200 \mathrm{~g} \mathrm{~mol}^{-1}$, mainly occupying the space close to the origin of the molecular corridor. Some products with higher molar mass $\left(>300 \mathrm{~g} \mathrm{~mol}^{-1}\right)$ are mainly first-generation products of ozonolysis of skin lipids, including hydroxyl geranyl acetone, polyunsaturated aldehydes, and fatty acids. These products can be further oxidized by ozone, generating fragmented secondary products with a relatively higher $\mathrm{O}: \mathrm{C}$ ratio with carbonyl, carboxyl, or $\alpha$ hydroxy ketone groups (Wisthaler and Weschler, 2010). 

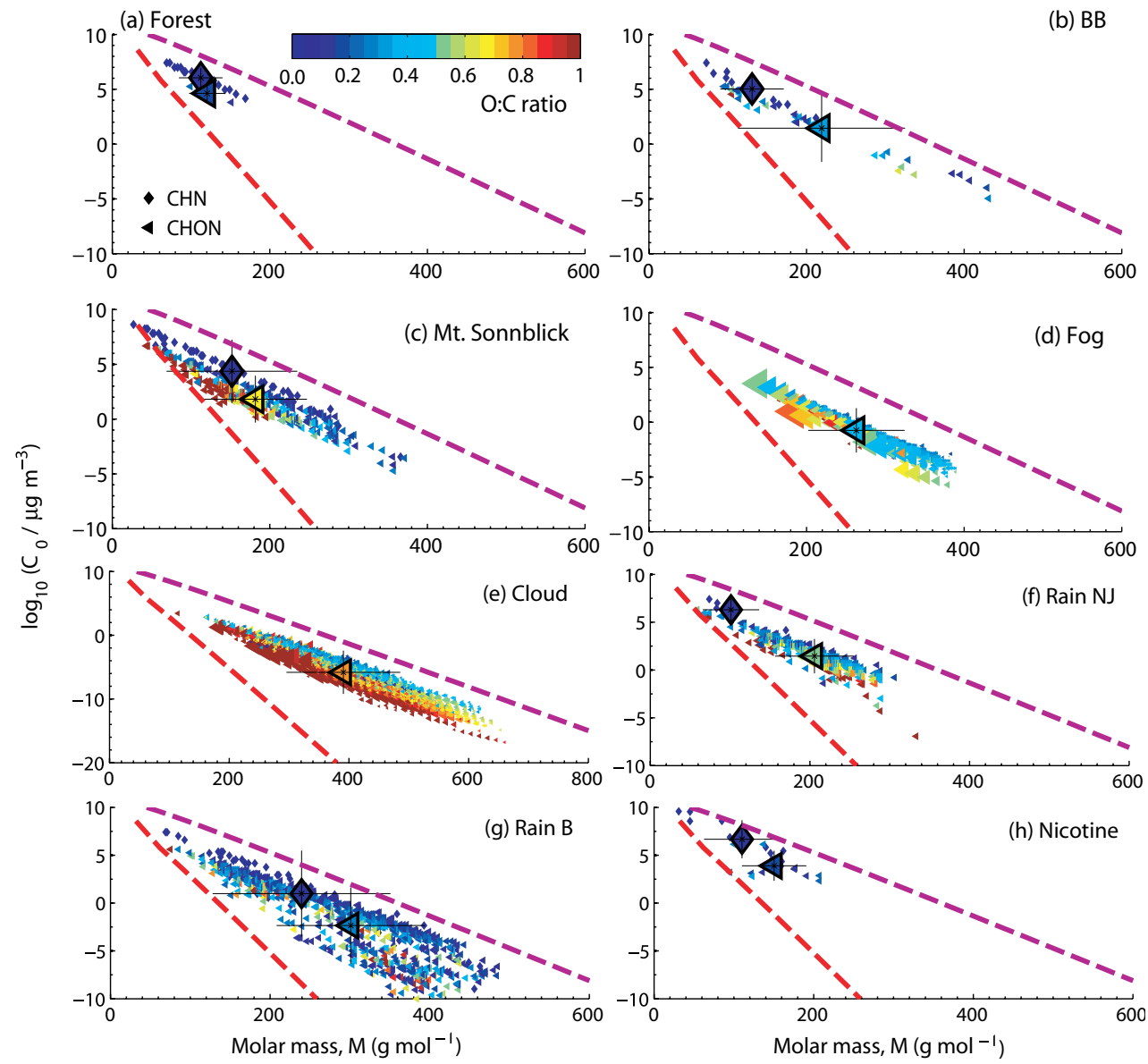

Figure 6. Molecular corridors of saturation mass concentration $\left(C_{0}\right)$ vs. molar mass $(M)$ for N-containing compounds collected from (a) boreal forest (Ehn et al., 2010, 2012), (b) biomass burning (Laskin et al., 2009), (c) high alpine air at Mt. Sonnblick (Holzinger et al., 2010), (d) fog in Fresno (Mazzoleni et al., 2010), (e) cloud at Mt. Werner (Zhao et al., 2013), (f) rain in New Jersey (Altieri et al., 2009a, b), (g) rain in Bermuda (Altieri et al., 2012), and (h) tobacco smoke (Sleiman et al., 2010a, b). The small markers represent individual compounds color-coded by atomic $\mathrm{O}: \mathrm{C}$ ratio. The size of the small markers in (d) and (e) is linearly scaled by relative intensity of MS signal. The larger symbols with error bars indicate the surrogate compounds with the mean values of $M, C_{0}$, and $\mathrm{O}: \mathrm{C}$ ratio (relative abundance considered for $\mathbf{d}$ and $\mathbf{e}$ ).

Cigarette smoke is another pollutant frequently encountered in indoor air and residual secondhand tobacco smoke absorbed to indoor surfaces can react with atmospheric species such as ozone (Destaillats et al., 2006; Sleiman et al., 2010a) and nitrous acid (HONO) (Sleiman et al., 2010b) to form third-hand smoke hazards. As shown in Fig. 5h, most of the nicotine products have $M<300 \mathrm{~g} \mathrm{~mol}^{-1}$ and $\mathrm{O}: \mathrm{C}<0.5$ with $\log _{10} C_{0}>2 \mu \mathrm{g} \mathrm{m}^{-3}$. As oxidant levels in indoor air are relatively low compared to outdoor air (Weschler, 2011), indoor OA tend to be less oxidized and have lower molar mass.

\subsection{Nitrogen- and sulfur-containing compounds}

Figure 6 shows N-containing compounds plotted in the molecular corridor. Figure 6a shows 23 compounds observed at Hyytiälä, Finland, during NPF events (Ehn et al., 2010, 2012). They are mainly amines with a small molar mass range (69-169 $\mathrm{g} \mathrm{mol}^{-1}$ ) and intermediate volatility, covering the space close to the origin of the molecular corridor. Amines can stabilize sulfuric acid clusters efficiently and their role in nucleation may be significant (Loukonen et al., 2010; Smith et al., 2010; Wang et al., 2010; Erupe et al., 2011; Zhang et al., 2011; Kulmala et al., 2014).

$\mathrm{N}$-containing organic compounds are important components of biomass-burning organic aerosols (Lobert et al., 1990; Simoneit, 2002). Figure 6b presents these compounds including amine, urea, alkyl amide, alkyl nitrile, amino acid, and N-heterocyclic alkaloid compounds (Laskin et al., 2009). These compounds spread separately in two parts in molecular corridors. Some compounds are assembled in the upper left space bounded by $\log _{10} C_{0}>0 \mu \mathrm{g} \mathrm{m} \mathrm{m}^{-3}$ and $M<300 \mathrm{~g} \mathrm{~mol}^{-1}$. A part of these compounds may be a consequence of oxidative fragmentation or thermal decomposition. Compounds clustered in the lower right space are 

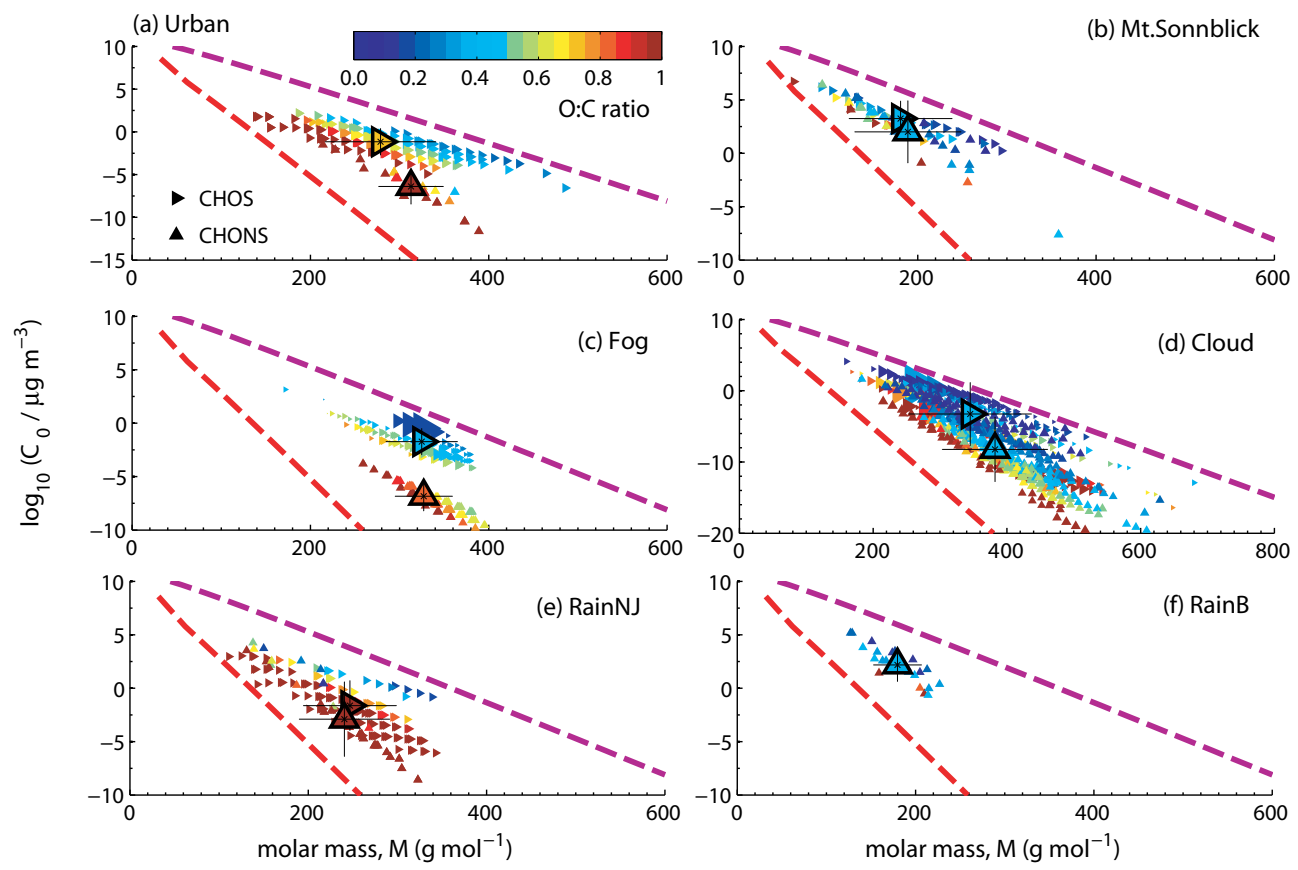

Figure 7. Molecular corridors of saturation mass concentration $\left(C_{0}\right)$ vs. molar mass $(M)$ for S-containing compounds collected from (a) urban areas including Shanghai (Ma et al., 2014; Tao et al., 2014) and Guangzhou (Lin et al., 2012), Taipei (Lin et al., 2012), Lahore (Stone et al., 2012), Bakersfield (O’Brien et al., 2014) and Los Angeles (Tao et al., 2014), (b) Mt. Sonnblick (Holzinger et al., 2010), (c) fog in Fresno (Mazzoleni et al., 2010), (d) cloud at Mt. Werner (Zhao et al., 2013), (e) rain in New Jersey (Altieri et al., 2009a, b), and (f) rain in Bermuda (Altieri et al., 2012). The small markers represent individual compounds color-coded by atomic $\mathrm{O}: \mathrm{C}$ ratio. The size of the small markers in (c) and (d) is linearly scaled by relative intensity of MS signal. The larger symbols with error bars indicate the surrogate compounds with the mean values of $M, C_{0}$, and $\mathrm{O}: \mathrm{C}$ ratio (relative abundance considered for $\mathbf{c}$ and $\mathbf{d}$ ).

CHON compounds with molar mass higher than $300 \mathrm{~g} \mathrm{~mol}^{-1}$ covering the range from LVOC to ELVOC.

More than $200 \mathrm{~N}$-containing compounds were identified at Mt. Sonnblick (Fig. 6c; Holzinger et al., 2010). Lessoxidized $\mathrm{N}$-containing organic compounds could be formed through reactions transforming carbonyls into imines or reactions of NO with organic peroxy radicals (O'Brien et al., 2014). Highly oxidized organonitrates $(\mathrm{O}: \mathrm{C}>1)$ were suggested to be formed by nitrate radical chemistry (Holzinger et al., 2010). Many highly oxidized N-containing compounds with a range of $\mathrm{O}: \mathrm{C}$ ratios from 1 to 2 were observed in fog (Fig. 6d; Mazzoleni et al., 2010), cloud (Fig. 6e; Zhao et al., 2013), rain in New Jersey (Fig. 6f; Altieri et al., 2009a, b), and Bermuda (Fig. 6g; Altieri et al., 2012). Aqueous-phase processing can form a variety of highly functionalized nitrated organic compounds including organonitrates, hydroxynitrates, carbonyl nitrates, and dinitrates (Zhao et al., 2013). Reduced nitrogen compounds were also identified in atmospheric water, mainly occupying the space close to the alkane line.

Figure 6h shows $\mathrm{N}$-containing compounds found in the secondhand and third-hand tobacco smoke. Nitrosamines were found in third-hand smoke hazards when the residual nicotine reacts with HONO (Sleiman et al., 2010b). Similar to the trend of $\mathrm{CHO}$ compounds in the molecular corridors
(Fig. 5h), N-containing compounds also mainly occupy the region close to the origin of the molecular corridor. Some high molar mass $\mathrm{N}$-containing compounds $(\mathrm{m} / z 400-500)$ were also detected, but their elemental compositions and structures have not been identified (Sleiman et al., 2010a).

Figure 7 shows S-containing compounds plotted in the molecular corridor. Organosulfate and nitrooxy organosulfate were frequently identified in fine aerosols especially in urban areas including Shanghai (Ma et al., 2014; Tao et al., 2014) and Guangzhou (Lin et al., 2012) in China, Taipei (Lin et al., 2012), Lahore in Pakistan (Stone et al., 2012), Bakersfield (O'Brien et al., 2014) and Los Angeles (Tao et al., 2014 ) in the USA as shown in Fig. 7a. Most of them are LVOC or ELVOC with O : C ratio higher than 0.8 and molar mass in $200-400 \mathrm{~g} \mathrm{~mol}^{-1}$. Some uncommon organosulfates with higher molar mass but a lower degree of oxidation were found in Shanghai, and long-chain alkanes from vehicle emissions were suggested to be their precursors (Tao et al., 2014). Compared to the organosulfates identified in urban areas, oxygenated sulfur-containing compounds characterized at Mt. Sonnblick have a relatively lower O: $\mathrm{C}$ ratio $(\sim 0.5$ in an average) and molar mass (mostly less than $250 \mathrm{~g} \mathrm{~mol}^{-1}$ ) and higher volatility (IVOC or SVOC) (Fig. 7b). Similar to highly oxidized N-containing compounds observed in fog, cloud, and rain, S-containing highly oxidized compounds 


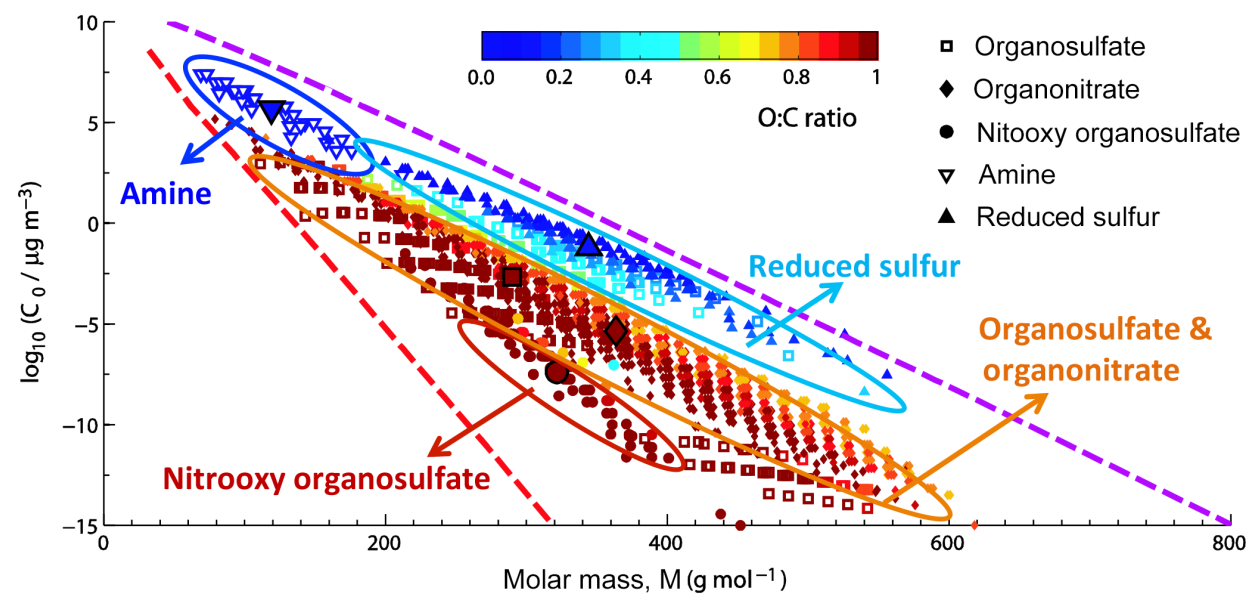

Figure 8. Molecular corridors of saturation mass concentration $\left(C_{0}\right)$ vs. molar mass $(M)$ for organosulfate, organonitrate, nitrooxy organosulfate, amine, and reduced sulfur compounds collected from outdoor observations (Table 2). The small markers represent individual compounds color-coded by $\mathrm{O}: \mathrm{C}$ ratio. The larger symbols indicate surrogate compounds with the mean values of $M, C_{0}$, and $\mathrm{O}: \mathrm{C}$ ratio.

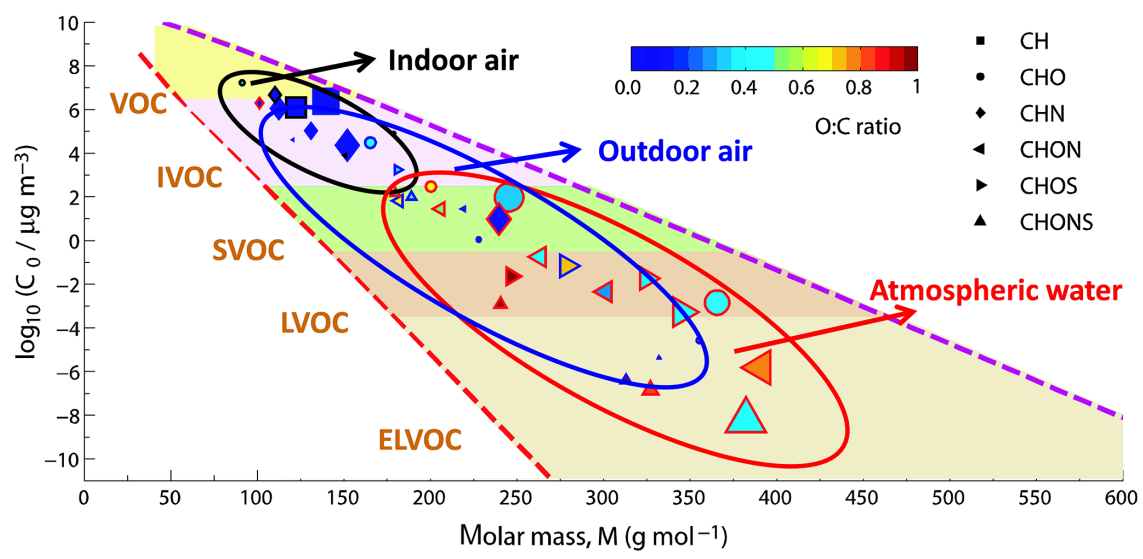

Figure 9. Average molecular corridors for OA observed in indoor air, outdoor air, and atmospheric water. The markers show surrogate compounds with the mean values of molar mass $(M)$, saturation mass concentration $\left(C_{0}\right)$, and $\mathrm{O}$ : C ratio computed from every observation event (Figs. 5-7). The edge color of the symbols indicates the surrogate compound identified in indoor air (black), outdoor air (blue), and atmospheric water (red). The symbol size is scaled by the ratio of the number of compounds in each class (e.g., $\mathrm{CH}, \mathrm{CHO}, \mathrm{CHON}, \mathrm{CHONS}$ ) to the total number of compounds in each data set.

including functionalized (nitro and nitrooxy) organosulfates were formed in atmospheric water (Fig. 7c-f), which was located close to the sugar alcohol line in the range of LVOC and ELVOC. Compounds close to the alkane line are mostly reduced sulfur compounds, e.g., aromatic structures containing only one $\mathrm{S}$ and one $\mathrm{O}$, which may be emitted from primary sources.

Figure 8 summarizes the molecular corridor for amine, organonitrate, organosulfate, nitrooxy organosulfate, and reduced sulfur compounds. The small markers are compounds identified in the studies included in Figs. 6 and 7. Among these species, nitrooxy organosulfates have the highest $\mathrm{O}: \mathrm{C}$ ratio $(>0.9)$ and the lowest volatility falling into the ELVOC group with molar mass up to $400 \mathrm{~g} \mathrm{~mol}^{-1}$. Organosulfates and organonitrates have an $\mathrm{O}: \mathrm{C}$ ratio gener- ally higher than 0.7, covering the range of IVOC to ELVOC with a broad molar mass range $\left(100-600 \mathrm{~g} \mathrm{~mol}^{-1}\right)$ to occupy the high $\mathrm{O}: \mathrm{C}$ corridor. Note that there exists a homologous series of organosulfates with molar mass between 400 and $600 \mathrm{~g} \mathrm{~mol}^{-1}$ and $\log _{10}\left(C_{0}\right)<-10$, which appear to have lower $\mathrm{d} \log C_{0} / \mathrm{d} M$ values. These compounds, e.g., $\mathrm{C}_{17} \mathrm{H}_{18} \mathrm{O}_{16} \mathrm{~S}_{1}, \mathrm{C}_{18} \mathrm{H}_{20} \mathrm{O}_{16} \mathrm{~S}_{1}$, and $\mathrm{C}_{19} \mathrm{H}_{22} \mathrm{O}_{16} \mathrm{~S}_{1}$, were found in the cloud water and their formation may be due to esterification of hydroxyl groups with sulfuric acid or acidcatalyzed reactions of epoxides (Zhao et al., 2013). Reduced sulfur compounds have low $\mathrm{O}: \mathrm{C}$ ratio $(<0.4)$ and are located close to the alkane line. Amine and N-heterocyclic alkaloid compounds found during new particle formation and biomass burning have the lowest $\mathrm{O}: \mathrm{C}$ ratio and molar mass 
and the highest volatility (in VOC and IVOC groups), following the low $\mathrm{O}: \mathrm{C}$ corridor.

\section{Summary and conclusions}

From the analysis of measured OA located into the molecular corridor, we can conclude that the molecular corridor characterized by molar mass, saturation mass concentration, and $\mathrm{O}: \mathrm{C}$ ratio has successfully grasped the properties of organic compounds from different sources and formed in various atmospheric conditions. Figure 9 shows the trend of observed organic compounds with surrogate compounds with the mean values of molar mass, saturation mass concentration, and $\mathrm{O}: \mathrm{C}$ ratio derived from every observation event. The symbol size is scaled with the ratio of the number of compound in each class (e.g., $\mathrm{CH}, \mathrm{CHO}, \mathrm{CHON}, \mathrm{CHONS}$ ) to the total number of compounds in each observation.

$\mathrm{OA}$ in indoor environments have relatively lower molar mass and higher volatility, mainly occupying the space close to the origin of the molecular corridor. Outdoor OA are constrained to a corridor in the range of IVOC-LVOC with a molar mass of up to $\sim 400 \mathrm{~g} \mathrm{~mol}^{-1}$. Atmospheric water of fog, cloud, and rain droplets often contain many highly oxygenated, high molar mass, and low-volatility compounds, extending to a wide space with higher molar mass and lower volatility. Molecular corridors are a useful framework for analysis and interpretation of measurements by a high-resolution mass spectrometer to visualize distribution of organic compounds providing insights into the evolution of OA properties.

Explicit consideration of molar mass in an OA model would also be useful in inferring particle-phase state (liquid vs. semisolid vs. amorphous solid), as the molar mass correlates with the glass transition temperature of organic compounds (Koop et al., 2011). The phase state has been shown to affect various gas-particle interactions including heterogeneous and multiphase chemistry, SOA formation and evolution as well as activation to cloud droplets and ice crystals (Pöschl and Shiraiwa, 2015, and references therein). Molecular corridors may serve as a basis for better treatment of SOA properties and interpretation of model outputs in detailed SOA models (e.g., Shiraiwa et al., 2012; Cappa et al., 2013; Roldin et al., 2014; Zaveri et al., 2014) as well as for compact representation of OA formation and evolution in regional and global models of climate and air quality.

\section{The Supplement related to this article is available online} at doi:10.5194/acp-16-3327-2016-supplement.
Acknowledgements. Ying Li was supported by the Lindau Fellowship (project no. GZ 1116), granted by the Sino-German Science Center. This work was supported by the Max Planck Society and the National Natural Science Foundation of China (grant no. 41405121). The authors gratefully acknowledge Lynn Mazzoleni (Michigan Technological University), Alexander Laskin (Pacific Northwest National Laboratory), Rupert Holzinger (Utrecht University), Neil Donahue (Carnegie Mellon University), Thomas Mentel (Research Center Jülich), Frank Wania (University of Toronto Scarborough), Yiyi Wei (Texas Tech University), Thomas Berkemeier (Max Planck Institute for Chemistry), Pascale Lakey (Max Planck Institute for Chemistry), and John Seinfeld (Caltech) for stimulating discussions. We thank Ulrich Krieger (ETH Zurich) and two anonymous referees for useful comments.

The article processing charges for this open-access publication were covered by the Max Planck Society.

Edited by: A. Kiendler-Scharr

\section{References}

Ahmadov, R., McKeen, S. A., Robinson, A. L., Bahreini, R., Middlebrook, A. M., de Gouw, J. A., Meagher, J., Hsie, E.Y., Edgerton, E., Shaw, S., and Trainer, M.: A volatility basis set model for summertime secondary organic aerosols over the eastern United States in 2006, J. Geophys. Res., 117, D06301, doi:10.1029/2011JD016831, 2012.

Altieri, K. E., Seitzinger, S. P., Clalton, A. G., Trupin, B. J., Klein, G. C., and Marshall, A. G.: Oligomers fromed through in-cloud methylglyoxal reactions: chemical composition, properties, and mechanisms investigated by ultra-high resolution FT-ICR mass spectrometry, Atmos. Environ., 42, 1476-1490, 2008.

Altieri, K. E., Turpin, B. J., and Seitzinger, S. P.: Composition of dissolved organic nitrogen in continental precipitation investigated by ultra-high resolution FT-ICR mass spectrometry, Environ. Sci. Technol., 43, 6950-6955, 2009a.

Altieri, K. E., Turpin, B. J., and Seitzinger, S. P.: Oligomers, organosulfates, and nitrooxy organosulfates in rainwater identified by ultra-high resolution electrospray ionization FTICR mass spectrometry, Atmos. Chem. Phys., 9, 2533-2542, doi:10.5194/acp-9-2533-2009, 2009b.

Altieri, K. E., Hastings, M. G., Peters, A. J., and Sigman, D. M.: Molecular characterization of water soluble organic nitrogen in marine rainwater by ultra-high resolution electrospray ionization mass spectrometry, Atmos. Chem. Phys., 12, 3557-3571, doi:10.5194/acp-12-3557-2012, 2012.

Barley, M. H. and McFiggans, G.: The critical assessment of vapour pressure estimation methods for use in modelling the formation of atmospheric organic aerosol, Atmos. Chem. Phys., 10, 749767, doi:10.5194/acp-10-749-2010, 2010.

Bilde, M., Barsanti, K., Booth, M., Cappa, C. D., Donahue, N. M., Emanuelsson, E. U., McFiggans, G., Krieger, U. K., Marcolli, C., Topping, D., Ziemann, P., Barley, M., Clegg, S., Dennis-Smither, B., Hallquist, M., Hallquist, Å. M., Khlystov, A., Kulmala, M., Mogensen, D., Percival, C. J., Pope, F., Reid, J. P., Ribeiro da Silva, M. A. V., Rosenoern, T., Salo, K., Soonsin, V. P., Yli-Juuti, T., Prisle, N. L., Pagels, J., Rarey, J., Zardini, A. A., and Riip- 
inen, I.: Saturation vapor pressures and transition enthalpies of low-volatility organic molecules of atmospheric relevance: from dicarboxylic acids to complex mixtures, Chem. Rev., 115, 41154156, 2015.

Boyd, C. M., Sanchez, J., Xu, L., Eugene, A. J., Nah, T., Tuet, W. Y., Guzman, M. I., and Ng, N. L.: Secondary organic aerosol formation from the $\beta$-pinene $+\mathrm{NO}_{3}$ system: effect of humidity and peroxy radical fate, Atmos. Chem. Phys., 15, 7497-7522, doi:10.5194/acp-15-7497-2015, 2015.

Cappa, C. D. and Jimenez, J. L.: Quantitative estimates of the volatility of ambient organic aerosol, Atmos. Chem. Phys., 10, 5409-5424, doi:10.5194/acp-10-5409-2010, 2010.

Cappa, C. D. and Wilson, K. R.: Multi-generation gas-phase oxidation, equilibrium partitioning, and the formation and evolution of secondary organic aerosol, Atmos. Chem. Phys., 12, 9505-9528, doi:10.5194/acp-12-9505-2012, 2012.

Cappa, C. D., Zhang, X., Loza, C. L., Craven, J. S., Yee, L. D., and Seinfeld, J. H.: Application of the Statistical Oxidation Model (SOM) to Secondary Organic Aerosol formation from photooxidation of $\mathrm{C}_{12}$ alkanes, Atmos. Chem. Phys., 13, 1591-1606, doi:10.5194/acp-13-1591-2013, 2013.

Carlton, A. G. and Turpin, B. J.: Particle partitioning potential of organic compounds is highest in the Eastern US and driven by anthropogenic water, Atmos. Chem. Phys., 13, 10203-10214, doi:10.5194/acp-13-10203-2013, 2013.

Chan, M. N., Nah, T., and Wilson, K. R.: Real time in situ chemical characterization of sub-micron organic aerosols using Direct Analysis in Real Time mass spectrometry (DART-MS): the effect of aerosol size and volatility, Analyst, 138, 3749-3757, 2013.

Clegg, S. L., Kleeman, M. J., Griffin, R. J., and Seinfeld, J. H.: Effects of uncertainties in the thermodynamic properties of aerosol components in an air quality model - Part 2: Predictions of the vapour pressures of organic compounds, Atmos. Chem. Phys., 8, 1087-1103, doi:10.5194/acp-8-1087-2008, 2008.

Compernolle, S., Ceulemans, K., and Müller, J.-F.: EVAPORATION: a new vapour pressure estimation methodfor organic molecules including non-additivity and intramolecular interactions, Atmos. Chem. Phys., 11, 9431-9450, doi:10.5194/acp-119431-2011, 2011.

Crounse, J. D., Nielsen, L. B., Jorgensen, S., Kjaergaard, H. G., and Wennberg, P. O.: Autoxidation of organic compounds in the atmosphere, J. Phys. Chem. Lett., 4, 3513-3520, 2013.

Daumit, K. E., Carrasquillo, A. J., Hunter, J. F., and Kroll, J. H.: Laboratory studies of the aqueous-phase oxidation of polyols: submicron particles vs. bulk aqueous solution, Atmos. Chem. Phys., 14, 10773-10784, doi:10.5194/acp-14-10773-2014, 2014.

Destaillats, H., Singer, B. C., Lee, S. K., and Gundel, L. A.: Effect of ozone on nicotine desorption from model surfaces?: evidence for heterogeneous Chemistry, Environ. Sci. Technol., 40, 17991805, 2006.

Donahue, N. M., Robinson, A. L., Stanier, C. O., and Pandis, S. N.: Coupled partitioning, dilution, and chemical aging of semivolatile organics, Environ. Sci. Technol., 40, 2635-2643, 2006.

Donahue, N. M., Epstein, S. A., Pandis, S. N., and Robinson, A. L.: A two-dimensional volatility basis set: 1. organic-aerosol mixing thermodynamics, Atmos. Chem. Phys., 11, 3303-3318, doi:10.5194/acp-11-3303-2011, 2011.
Donahue, N. M., Kroll, J. H., Pandis, S. N., and Robinson, A. L.: A two-dimensional volatility basis set - Part 2: Diagnostics of organic-aerosol evolution, Atmos. Chem. Phys., 12, 615-634, doi:10.5194/acp-12-615-2012, 2012.

Donahue, N. M., Robinson, A. L., Trump, E. R., Riipinen, I., and Kroll, J. H.: Volatility and aging of atmospheric organic aerosol, in: Atmospheric and Aerosol Chemistry, edited by: McNeill, V. F. and Ariya, P. A., Topics in Current Chemistry, 97-143, 2014.

Ehn, M., Junninen, H., Petäjä, T., Kurtén, T., Kerminen, V.-M., Schobesberger, S., Manninen, H. E., Ortega, I. K., Vehkamäki, H., Kulmala, M., and Worsnop, D. R.: Composition and temporal behavior of ambient ions in the boreal forest, Atmos. Chem. Phys., 10, 8513-8530, doi:10.5194/acp-10-8513-2010, 2010.

Ehn, M., Kleist, E., Junninen, H., Petäjä, T., Lönn, G., Schobesberger, S., Dal Maso, M., Trimborn, A., Kulmala, M., Worsnop, D. R., Wahner, A., Wildt, J., and Mentel, Th. F.: Gas phase formation of extremely oxidized pinene reaction products in chamber and ambient air, Atmos. Chem. Phys., 12, 5113-5127, doi:10.5194/acp-12-5113-2012, 2012.

Ehn, M., Thornton, J. A., Kleist, E., Sipila, M., Junninen, H., Pullinen, I., Springer, M., Rubach, F., Tillmann, R., Lee, B., LopezHilfiker, F., Andres, S., Acir, I. H., Rissanen, M., Jokinen, T., Schobesberger, S., Kangasluoma, J., Kontkanen, J., Nieminen, T., Kurten, T., Nielsen, L. B., Jorgensen, S., Kjaergaard, H. G., Canagaratna, M., Dal Maso, M., Berndt, T., Petaja, T., Wahner, A., Kerminen, V. M., Kulmala, M., Worsnop, D. R., Wildt, J., and Mentel, T. F.: A large source of low-volatility secondary organic aerosol, Nature, 506, 476-479, 2014.

Epstein, S. A., Riipinen, I., and Donahue, N. M.: A semiempirical correlation between enthalpy of vaporization and saturation concentration for organic aerosol, Environ. Sci. Technol., 44, 743748, 2010.

Erupe, M. E., Viggiano, A. A., and Lee, S.-H.: The effect of trimethylamine on atmospheric nucleation involving $\mathrm{H}_{2} \mathrm{SO}_{4}$, Atmos. Chem. Phys., 11, 4767-4775, doi:10.5194/acp-11-47672011, 2011.

Ervens, B.: Modeling the processing of aerosol and trace gases in clouds and fogs, Chem. Rev., 115, 4157-4198, 2015.

Ervens, B., Turpin, B. J., and Weber, R. J.: Secondary organic aerosol formation in cloud droplets and aqueous particles (aqSOA): a review of laboratory, field and model studies, Atmos. Chem. Phys., 11, 11069-11102, doi:10.5194/acp-1111069-2011, 2011.

Farmer, D. K., Matsunaga, A., Docherty, K. S., Surratt, J. D., Seinfeld, J. H., Ziemann, P. J., and Jimenez, J. L.: Response of an aerosol mass spectrometer to organonitrates and organosulfates and implications for atmospheric chemistry, P. Natl. Acad. Sci. USA, 107, 6670-6675, 2010.

Fry, J. L., Draper, D. C., Zarzana, K. J., Campuzano-Jost, P., Day, D. A., Jimenez, J. L., Brown, S. S., Cohen, R. C., Kaser, L., Hansel, A., Cappellin, L., Karl, T., Hodzic Roux, A., Turnipseed, A., Cantrell, C., Lefer, B. L., and Grossberg, N.: Observations of gas- and aerosol-phase organic nitrates at BEACHON-RoMBAS 2011, Atmos. Chem. Phys., 13, 8585-8605, doi:10.5194/acp-138585-2013, 2013.

Fuzzi, S., Baltensperger, U., Carslaw, K., Decesari, S., Denier van der Gon, H., Facchini, M. C., Fowler, D., Koren, I., Langford, B., Lohmann, U., Nemitz, E., Pandis, S., Riipinen, I., Rudich, Y., Schaap, M., Slowik, J. G., Spracklen, D. V., Vignati, E., Wild, 
M., Williams, M., and Gilardoni, S.: Particulate matter, air quality and climate: lessons learned and future needs, Atmos. Chem. Phys., 15, 8217-8299, doi:10.5194/acp-15-8217-2015, 2015.

Gómez-González, Y., Wang, W., Vermeylen, R., Chi, X., Neirynck, J., Janssens, I. A., Maenhaut, W., and Claeys, M.: Chemical characterisation of atmospheric aerosols during a 2007 summer field campaign at Brasschaat, Belgium: sources and source processes of biogenic secondary organic aerosol, Atmos. Chem. Phys., 12, 125-138, doi:10.5194/acp-12-125-2012, 2012.

Hamilton, J. F., Baeza-Romero, M. T., Finessi, E., Rickard, A. R., Healy, R. M., Peppe, S., Adams, T. J., Daniels, M. J. S., Ball, S. M., Goodall, I. C. A., Monks, P. S., Borrás, E., and Muñoz, A.: Online and offline mass spectrometric study of the impact of oxidation and ageing on glyoxal chemistry and uptake onto ammonium sulfate aerosols, Faraday Discuss., 165, 447-472, 2013.

Hallquist, M., Wenger, J. C., Baltensperger, U., Rudich, Y., Simpson, D., Claeys, M., Dommen, J., Donahue, N. M., George, C., Goldstein, A. H., Hamilton, J. F., Herrmann, H., Hoffmann, T., Iinuma, Y., Jang, M., Jenkin, M. E., Jimenez, J. L., Kiendler-Scharr, A., Maenhaut, W., McFiggans, G., Mentel, Th. F., Monod, A., Prévôt, A. S. H., Seinfeld, J. H., Surratt, J. D., Szmigielski, R., and Wildt, J.: The formation, properties and impact of secondary organic aerosol: current and emerging issues, Atmos. Chem. Phys., 9, 5155-5236, doi:10.5194/acp-9-51552009, 2009.

Hayes, P. L., Carlton, A. G., Baker, K. R., Ahmadov, R., Washenfelder, R. A., Alvarez, S., Rappenglück, B., Gilman, J. B., Kuster, W. C., de Gouw, J. A., Zotter, P., Prévôt, A. S. H., Szidat, S., Kleindienst, T. E., Offenberg, J. H., Ma, P. K., and Jimenez, J. L.: Modeling the formation and aging of secondary organic aerosols in Los Angeles during CalNex 2010, Atmos. Chem. Phys., 15, 5773-5801, doi:10.5194/acp-15-5773-2015, 2015.

Heald, C. L., Kroll, J. H., Jimenez, J. L., Docherty, K. S., DeCarlo, P. F., Aiken, A. C., Chen, Q., Martin, S. T., Farmer, D. K., and Artaxo, P.: A simplified description of the evolution of organic aerosol composition in the atmosphere, Geophys. Res. Lett., 37, L08803, doi:10.1029/2010g1042737, 2010.

Holzinger, R., Goldstein, A. H., Hayes, P. L., Jimenez, J. L., and Timkovsky, J.: Chemical evolution of organic aerosol in Los Angeles during the CalNex 2010 study, Atmos. Chem. Phys., 13, 10125-10141, doi:10.5194/acp-13-10125-2013, 2013.

Holzinger, R., Kasper-Giebl, A., Staudinger, M., Schauer, G., and Röckmann, T.: Analysis of the chemical composition of organic aerosol at the Mt. Sonnblick observatory using a novel high mass resolution thermal-desorption proton-transfer-reaction mass-spectrometer (hr-TD-PTR-MS), Atmos. Chem. Phys., 10, 10111-10128, doi:10.5194/acp-10-10111-2010, 2010.

Huang, R. J., Zhang, Y. L., Bozzetti, C., Ho, K. F., Cao, J. J., Han, Y. M., Daellenbach, K. R., Slowik, J. G., Platt, S. M., Canonaco, F., Zotter, P., Wolf, R., Pieber, S. M., Bruns, E. A., Crippa, M., Ciarelli, G., Piazzalunga, A., Schwikowski, M., Abbaszade, G., Schnelle-Kreis, J., Zimmermann, R., An, Z. S., Szidat, S., Baltensperger, U., El Haddad, I., and Prevot, A. S. H.: High secondary aerosol contribution to particulate pollution during haze events in China, Nature, 514, 218-222, 2014.

Huisman, A. J., Krieger, U. K., Zuend, A., Marcolli, C., and Peter, T.: Vapor pressures of substituted polycarboxylic acids are much lower than previously reported, Atmos. Chem. Phys., 13, 66476662, doi:10.5194/acp-13-6647-2013, 2013.
Iinuma, Y., Muller, C., Berndt, T., Boge, O., Claeys, M., and Herrmann, H.: Evidence for the existence of organosulfates from beta-pinene ozonolysis in ambient secondary organic aerosol, Environ. Sci. Technol., 41, 6678-6683, 2007.

Jathar, S. H., Miracolo, M. A., Presto, A. A., Donahue, N. M., Adams, P. J., and Robinson, A. L.: Modeling the formation and properties of traditional and non-traditional secondary organic aerosol: problem formulation and application to aircraft exhaust, Atmos. Chem. Phys., 12, 9025-9040, doi:10.5194/acp-12-90252012, 2012.

Jimenez, J. L., Canagaratna, M. R., Donahue, N. M., Prevot, A. S. H., Zhang, Q., Kroll, J. H., DeCarlo, P. F., Allan, J. D., Coe, H., Ng, N. L., Aiken, A. C., Docherty, K. S., Ulbrich, I. M., Grieshop, A. P., Robinson, A. L., Duplissy, J., Smith, J. D., Wilson, K. R., Lanz, V. A., Hueglin, C., Sun, Y. L., Tian, J., Laaksonen, A., Raatikainen, T., Rautiainen, J., Vaattovaara, P., Ehn, M., Kulmala, M., Tomlinson, J. M., Collins, D. R., Cubison, M. J., Dunlea, E. J., Huffman, J. A., Onasch, T. B., Alfarra, M. R., Williams, P. I., Bower, K., Kondo, Y., Schneider, J., Drewnick, F., Borrmann, S., Weimer, S., Demerjian, K., Salcedo, D., Cottrell, L., Griffin, R., Takami, A., Miyoshi, T., Hatakeyama, S., Shimono, A., Sun, J. Y., Zhang, Y. M., Dzepina, K., Kimmel, J. R., Sueper, D., Jayne, J. T., Herndon, S. C., Trimborn, A. M., Williams, L. R., Wood, E. C., Middlebrook, A. M., Kolb, C. E., Baltensperger, U., and Worsnop, D. R.: Evolution of Organic Aerosols in the Atmosphere, Science, 326, 1525-1529, 2009.

Kahnt, A., Behrouzi, S., Vermeylen, R., Shalamzari, M. S., Vercauteren, J., Roekens, E., Claeys, M., and Maenhaut, W.: Oneyear study of nitro-organic sompounds and their relation to wood burning in $\mathrm{PM}_{10}$ aerosol from a rural site in Belgium, Atmos. Environ., 81, 561-568, 2013.

Kampf, C. J., Bonn, B., and Hoffmann, T.: Development and validation of a selective HPLC-ESI-MS/MS method for the quantification of glyoxal and methylglyoxal in atmospheric aerosols $\left(\mathrm{PM}_{2.5}\right)$, Anal. Bioanal. Chem., 401, 3115-3124, 2011.

Kanakidou, M., Seinfeld, J. H., Pandis, S. N., Barnes, I., Dentener, F. J., Facchini, M. C., Van Dingenen, R., Ervens, B., Nenes, A., Nielsen, C. J., Swietlicki, E., Putaud, J. P., Balkanski, Y., Fuzzi, S., Horth, J., Moortgat, G. K., Winterhalter, R., Myhre, C. E. L., Tsigaridis, K., Vignati, E., Stephanou, E. G., and Wilson, J.: Organic aerosol and global climate modelling: a review, Atmos. Chem. Phys., 5, 1053-1123, doi:10.5194/acp-5-1053-2005, 2005.

Kitanovski, Z., Grgić, I., Vermeylen, R., Claeys, M., and Maenhaut, W.: Liquid chromatography tandem mass spectrometry method for characterization of monoaromatic nitro-compounds in atmospheric particulate matter, J. Chromatogr. A, 1268, 35-43, 2012.

Koop, T., Bookhold, J., Shiraiwa, M., and Pöschl, U.: Glass transition and phase state of organic compounds: dependency on molecular properties and implications for secondary organic aerosols in the atmosphere, Phys. Chem. Chem. Phys., 13, 19238-19255, 2011.

Kourtchev, I., O’Connor, I. P., Giorio, C., Fuller, S. J., Kristensen, K., Maenhaut, W., Wenger, J. C., Sodeau, J. R., Glasius, M., and Kalberer, M.: Effects of anthropogenic emissions on the molecular composition of urban organic aerosols: An untrahigh resolution mass spectrometry study, Atmos. Environ., 89, 525-532, 2014. 
Krieger, U. K., Marcolli, C., and Reid, J. P.: Exploring the complexity of aerosol particle properties and processes using single particle techniques, Chem. Soc. Rev., 41, 6631-6662, 2012.

Kroll, J. H., Donahue, N. M., Jimenez, J. L., Kessler, S. H., Canagaratna, M. R., Wilson, K. R., Altieri, K. E., Mazzoleni, L. R., Wozniak, A. S., Bluhm, H., Mysak, E. R., Smith, J. D., Kolb, C. E., and Worsnop, D. R.: Carbon oxidation state as a metric for describing the chemistry of atmospheric organic aerosol, Nature Chemistry, 3, 133-139, 2011.

Kroll, J. H. and Seinfeld, J. H.: Chemistry of secondary organic aerosol: Formation and evolution of low-volatility organics in the atmosphere, Atmos. Environ., 42, 3593-3624, 2008.

Kulmala, M., Kontkanen, J., Junninen, H., Lehtipalo, K., Manninen, H. E., Nieminen, T., Petäjä, T., Sipilä, M., Schobesberger, S., Rantala, P., Franchin, A., Jokinen, T., Järvinen, E., Äijälä, M., Kangasluoma, J., Hakala, J., Aalto, P. P., Paasonen, P., Mikkilä, J., Vanhanen, J., Aalto, J., Hakola, H., Makkonen, U., Ruuskanen, T., Mauldin III, R. L., Duplissy, J., Vehkamäki, H., Bäck, J., Kortelainen, A., Riipinen, I., Kurtén, T., Johnston, M. V., Smith, J. M., Ehn, M., Mentel, Th. F., Lehtinen, K. E., Laaksonen, A., Kerminen, V.-M., and Worsnop, D. R.: Direct observation of atmospheric aerosol nucleation, Science, 339, 943-946, 2013.

Kulmala, M., Petäjä, T., Ehn, M., Thornton, J., Sipilä, M., Worsnop, D. R., and Kerminen, V.-M.: Chemistry of atmospheric nucleation: on the recent advances on precursor characterization and atmospheric cluster composition in connection with atmospheric new particle formation, Annu. Rev. Phys. Chem., 65, 21-37, 2014.

Kundu, S., Quraishi, T. A., Yu, G., Suarez, C., Keutsch, F. N., and Stone, E. A.: Evidence and quantitation of aromatic organosulfates in ambient aerosols in Lahore, Pakistan, Atmos. Chem. Phys., 13, 4865-4875, doi:10.5194/acp-13-4865-2013, 2013.

Lane, T. E., Donahue, N. M., and Pandis, S. N.: Simulating secondary organic aerosol formation using the volatility basis-set approach in a chemical transport model, Atmos. Environ., 42, 7439-7451, 2008.

Laskin, A., Laskin, J., and Nizkorodov, S. A.: Mass spectrometric approaches for chemical characterisation of atmospheric aerosols: critical review of the most recent advances, Environ. Chem., 9, 163-189, 2012.

Laskin, A., Smith, J. S., and Laskin, J.: Molecular Characterization of Nitrogen-Containing Organic Compounds in Biomass Burning Aerosols Using High-Resolution Mass Spectrometry, Environ. Sci. Technol., 43, 3764-3771, 2009.

Lim, Y. B., Tan, Y., Perri, M. J., Seitzinger, S. P., and Turpin, B. J.: Aqueous chemistry and its role in secondary organic aerosol (SOA) formation, Atmos. Chem. Phys., 10, 1052110539, doi:10.5194/acp-10-10521-2010, 2010.

Lin, P., Yu, J., Engling, G., and Kalberer, M.: Organosulfates in humic-like substance fraction isolated from aerosols at seven locations in East Asia: a study by ultra-high-resolution mass spectrometry, Environ. Sci. Technol., 46, 13118-13127, 2012.

Lobert, J. M., Scharffe, D. H., Hao, W. M., and Crutzen, P. J.: Importance of biomass burning in the atmospheric budgets of nitrogencontaining gases, Nature, 346, 552-554, 1990.

Loukonen, V., Kurtén, T., Ortega, I. K., Vehkamäki, H., Pádua, A. A. H., Sellegri, K., and Kulmala, M.: Enhancing effect of dimethylamine in sulfuric acid nucleation in the presence of wa- ter - a computational study, Atmos. Chem. Phys., 10, 49614974, doi:10.5194/acp-10-4961-2010, 2010.

Lukács, H., Gelencsér, A., Hoffer, A., Kiss, G., Horváth, K., and Hartyáni, Z.: Quantitative assessment of organosulfates in sizesegregated rural fine aerosol, Atmos. Chem. Phys., 9, 231-238, doi:10.5194/acp-9-231-2009, 2009.

Lyman, W. J.: Environmental exposure from chemicals, Volume I, edited by: Neely, W. B. and Blau, G. E. Boca Raton, FL, CRC Press, Inc., Chapter 2, 1985.

Lyman, W. J., Reehl, W. F., and Rosenblatt, D. H.: Handbook of chemical property estimation methods, Washington, DC: American Chemical Society, Chapter 14, 1990.

Ma, Y., Xu, X., Song, W., Geng, F., and Wang, L.: Seasonal and diurnal variations of particulate organosulfates in urban Shanghai, China, Atmos. Environ., 85, 152-160, 2014.

Matsui, H., Koike, M., Kondo, Y., Takami, A., Fast, J. D., Kanaya, Y., and Takigawa, M.: Volatility basis-set approach simulation of organic aerosol formation in East Asia: implications for anthropogenic-biogenic interaction and controllable amounts, Atmos. Chem. Phys., 14, 9513-9535, doi:10.5194/acp-14-95132014, 2014.

Mazzoleni, L. R., Ehrmann, B. M., Shen, X. H., Marshall, A. G., and Collett, J. L.: Water-soluble atmospheric organic matter in fog: exact masses and chemical formula identification by ultrahigh-resolution Fourier transform ion cyclotron resonance mass spectrometry, Environ. Sci. Technol., 44, 3690-3697, 2010.

McNeill, V. F., Woo, J. L., Kim, D. D., Schwier, A. N., Wannell, N. J., Sumner, A. J., and Barakat, J. M.: Aqueous-phase secondary organic aerosol and organosulfate formation in atmospheric aerosols: a modeling study, Environ. Sci. Technol., 46, 8075-8081, 2012.

Mead, R. N., Felix, J. D., Avery, G. B., Kieber, R. J., Willey, J. D., and Podgorski, D. C.: Characterization of CHOS compounds in rainwater from continental and coastal storms by ultrahigh resolution mass spectrometry, Atmos. Environ., 105, 162-168, 2015.

Mentel, T. F., Springer, M., Ehn, M., Kleist, E., Pullinen, I., Kurtén, T., Rissanen, M., Wahner, A., and Wildt, J.: Formation of highly oxidized multifunctional compounds: autoxidation of peroxy radicals formed in the ozonolysis of alkenes - deduced from structure-product relationships, Atmos. Chem. Phys., 15, 67456765, doi:10.5194/acp-15-6745-2015, 2015.

Mentel, Th. F., Wildt, J., Kiendler-Scharr, A., Kleist, E., Tillmann, R., Dal Maso, M., Fisseha, R., Hohaus, Th., Spahn, H., Uerlings, R., Wegener, R., Griffiths, P. T., Dinar, E., Rudich, Y., and Wahner, A.: Photochemical production of aerosols from real plant emissions, Atmos. Chem. Phys., 9, 4387-4406, doi:10.5194/acp9-4387-2009, 2009.

Morino, Y., Tanabe, K., Sato, K., and Ohara, T.: Secondary organic aerosol model intercomparision based on secondary organic aerosol to odd oxygen ratio in Tokyo, J. Geophys. Res.Atmos., 119, 13489-13505, 2014.

Murphy, B. N., Donahue, N. M., Fountoukis, C., Dall'Osto, M., O'Dowd, C., Kiendler-Scharr, A., and Pandis, S. N.: Functionalization and fragmentation during ambient organic aerosol aging: application of the 2-D volatility basis set to field studies, Atmos. Chem. Phys., 12, 10797-10816, doi:10.5194/acp-1210797-2012, 2012.

Murphy, B. N., Donahue, N. M., Robinson, A. L., and Pandis, S. N.: A naming convention for atmospheric organic aerosol, At- 
mos. Chem. Phys., 14, 5825-5839, doi:10.5194/acp-14-58252014, 2014.

Murphy, B. N. and Pandis, S. N.: Simulating the formation of semivolatile primary and secondary organic aerosol in a regional chemical transport model, Environ. Sci. Technol., 43, 47224728, 2009.

Nizkorodov, S. A., Laskin, J., and Laskin, A.: Molecular chemistry of organic aerosols through the application of high resolution mass spectrometry, Phys. Chem. Chem. Phys., 13, 3612-3629, 2011.

Nozière, B., Kalberer, M., Claeys, M., Allan, J., D’Anna, B., Decesari, S., Finessi, E., Glasius, M., Grgić, I., Hamilton, J. F., Hoffmann, T., Iinuma, Y., Jaoui, M., Kahnt, A., Kampf, C. J., Kourtchev, I., Maenhaut, W., Marsden, N., Saarikoski, S., Schnelle-Kreis, J., Surratt, J. D., Szidat, S., Szmigielski, R., and Wisthaler, A.: The molecular identification of organic compounds in the atmosphere: state of the art and challenges, Chem. Rev., 115, 3919-3983, 2015.

O’Brien, R. E., Laskin, A., Laskin, J., Rubitschun, C. L., Surratt, J. D., and Goldstein, A. H.: Molecular characterization of S- and $\mathrm{N}$-containing organic constituents in ambient aerosols by negative ion mode high-resolution Nanospray Desorption Electrospray Ionization Mass spectrometry: CalNex 2010 field study, J. Geophys. Res. Atmos., 119, 12706-12720, 2014.

Odum, J. R., Hoffmann, T., Bowman, F., Collins, D., Flagan, R. C., and Seinfeld, J. H.: Gas/particle partitioning and secondary organic aerosol yields, Environ. Sci. Technol., 30, 2580-2585, 1996.

O’Meara, S., Booth, A. M., Barley, M. H., Topping, D., and McFiggans, G.: An assessment of vapour pressure estimation methods, Phys. Chem. Chem. Phys., 16, 19453-19469, 2014.

Pankow, J. F.: An absorption-model of the gas aerosol partitioning involved in the formation of secondary organic aerosol, Atmos. Environ., 28, 189-193, 1994.

Pankow, J. F. and Barsanti, K. C.: The carbon number-polarity grid: A means to manage the complexity of the mix of organic compounds when modeling atmospheric organic particulate matter, Atmos. Environ., 43, 2829-2835, 2009.

Pöschl, U. and Shiraiwa, M.: Multiphase chemistry at the atmosphere-biosphere interface influencing climate and public health in the anthropocene, Chem. Rev., 115, 4440-4475, 2015.

Reemtsma, T.: Determination of molecular formulas of natural organic matter molecules by (ultra-) high-resolution mass spectrometry: status and needs, J. Chromatogr. A, 1216, 3687-3701, 2009.

Riccobono, F., Schobesberger, S., Scott, C. E., Dommen, J., Ortega, I. K., Rondo, L., Almeida, J., Amorim, A., Bianchi, F., Breitenlechner, M., David, A., Downard, A., Dunne, E. M., Duplissy, J., Ehrhart, S., Flagan, R. C., Franchin, A., Hansel, A., Junninen, H., Kajos, M., Keskinen, H., Kupc, A., Kuerten, A., Kvashin, A. N., Laaksonen, A., Lehtipalo, K., Makhmutov, V., Mathot, S., Nieminen, T., Onnela, A., Petaja, T., Praplan, A. P., Santos, F. D., Schallhart, S., Seinfeld, J. H., Sipilä, M., Spracklen, D. V., Stozhkov, Y., Stratmann, F., Tome, A., Tsagkogeorgas, G., Vaattovaara, P., Viisanenm Y., Vrtala, A., Wagner, P. E., Wein gartner, E., Wex, H., Wimmer, D., Carslaw, K. S., Curtius, J., Donahue, N. M., Kirkby, J., Kulmala, M., Worsnop, D. R., and Baltensperger, U.: Oxidation products of biogenic emissions con- tribute to nucleation of atmospheric particles, Science, 344, 717721, 2014.

Riipinen, I., Yli-Juuti, T., Pierce, J. R., Petaja, T., Worsnop, D. R., Kulmala, M., and Donahue, N. M.: The contribution of organics to atmospheric nanoparticle growth, Nat. Geosci., 5, 453-458, 2012.

Roldin, P., Eriksson, A. C., Nordin, E. Z., Hermansson, E., Mogensen, D., Rusanen, A., Boy, M., Swietlicki, E., Svenningsson, B., Zelenyuk, A., and Pagels, J.: Modelling non-equilibrium secondary organic aerosol formation and evaporation with the aerosol dynamics, gas- and particle-phase chemistry kinetic multilayer model ADCHAM, Atmos. Chem. Phys., 14, 7953-7993, doi:10.5194/acp-14-7953-2014, 2014.

Rollins, A. W., Browne, E. C., Min, K.-E., Pusede, S. E., Wooldridge, P. J., Gentner, D. R., Goldstein, A. H., Liu, S., Day, D. A., Russell, L. M., and Cohen, R. C.: Evidence for $\mathrm{NO}_{x}$ control over nighttime SOA formation, Science, 337, 1210-1212, 2012.

Romero, F. and Oehme, M.: Organosulfates - A new component of humic-like substances in atmospheric aerosols?, J. Atmos. Chem., 52, 283-294, 2005.

Schmitt-Kopplin, P., Gelencsér, A., Dabek-Zlotorzynska, E., Kiss, G., Norbert, H., Harir, M., Hong, Y., and Gebefügi, I.: Analysis of the unresolved organic fraction in atmospheric aerosols with Ultrahigh-Resolution Mass Spectrometry and Nuclear Magnetic Resonance Spectroscopy: organosulfates as photochemical smog constituents, Anal. Chem., 82, 8017-8026, 2010.

Schobesberger, S., Junninen, H., Bianchi, F., Lonn, G., Ehn, M., Lehtipalo, K., Dommen, J., Ehrhart, S., Ortega, I. K., Franchin, A., Nieminen, T., Riccobono, F., Hutterli, M., Duplissy, J., Almeida, J., Amorim, A., Breitenlechner, M., Downard, A. J., Dunne, E. M., Flagan, R. C., Kajos, M., Keskinen, H., Kirkby, J., Kupc, A., Kurten, A., Kurten, T., Laaksonen, A., Mathot, S., Onnela, A., Praplan, A. P., Rondo, L., Santos, F. D., Schallhart, S., Schnitzhofer, R., Sipila, M., Tome, A., Tsagkogeorgas, G., Vehkamaki, H., Wimmer, D., Baltensperger, U., Carslaw, K. S., Curtius, J., Hansel, A., Petaja, T., Kulmala, M., Donahue, N. M., and Worsnop, D. R.: Molecular understanding of atmospheric particle formation from sulfuric acid and large oxidized organic molecules, P. Natl. Acad. Sci. USA, 110, 17223-17228, 2013.

Shiraiwa, M., Pfrang, C., Koop, T., and Pöschl, U.: Kinetic multilayer model of gas-particle interactions in aerosols and clouds (KM-GAP): linking condensation, evaporation and chemical reactions of organics, oxidants and water, Atmos. Chem. Phys., 12, 2777-2794, 2012.

Shiraiwa, M., Yee, L. D., Schilling, K. A., Loza, C. L., Craven, J. S., Zuend, A., Ziemann, P. J., and Seinfeld, J. H.: Size distribution dynamics reveal particle-phase chemistry in organic aerosol formation, P. Natl. Acad. Sci. USA, 110, 11746-11750, 2013a.

Shiraiwa, M., Zuend, A., Bertram, A. K., and Seinfeld, J. H.: Gasparticle partitioning of atmospheric aerosols: interplay of physical state, non-ideal mixing and morphology, Phys. Chem. Chem. Phys., 15, 11441-11453, 2013b.

Shiraiwa, M., Berkemeier, T., Schilling-Fahnestock, K. A., Seinfeld, J. H., and Pöschl, U.: Molecular corridors and kinetic regimes in the multiphase chemical evolution of secondary organic aerosol, Atmos. Chem. Phys., 14, 8323-8341, doi:10.5194/acp-14-8323-2014, 2014. 
Shrivastava, M., Fast, J., Easter, R., Gustafson Jr., W. I., Zaveri, R. A., Jimenez, J. L., Saide, P., and Hodzic, A.: Modeling organic aerosols in a megacity: comparison of simple and complex representations of the volatility basis set approach, Atmos. Chem. Phys., 11, 6639-6662, doi:10.5194/acp-11-6639-2011, 2011.

Simoneit, B. R. T.: Biomass burning - A review of organic tracers for smoke from incomplete combustion, Appl. Geochem., 17, 129-162, 2002.

Sleiman, M., Destaillats, H., Smith, J. D., Liu, C. L., Ahmed, M., Wilson, K. R., and Gundel, L. A.: Secondary organic aerosol formation from ozone-initiated reactions with nicotine and secondhand tobacco smoke, Atmos. Environ., 44, 4191-4198, 2010a.

Sleiman, M., Gundel, L. A., Pankow, J. F., Jacob, P., Singer, B. C., and Destaillats, H.: Formation of carcinogens indoors by surfacemediated reactions of nicotine with nitrous acid, leading to potential thirdhand smoke hazards, P. Natl. Acad. Sci. USA, 107, 6576-6581, 2010b.

Smith, J. N., Barsanti, K. C., Friedli, H. R., Ehn, M., Kulmala, M., Collins, D. R., Scheckman, J. H., Williams, B. J., and McMurry, P. H.: Observations of aminium salts in atmospheric nanoparticles and possible climatic implications, P. Natl. Acad. Sci. USA, 107, 6634-6639, 2010.

Staudt, S., Kundu, S., Lehmler, H.-J., He, X., Cui, T., Lin, Y.-H., Kristensen, K., Glasius, M., Zhang, X., Weber, R. J., Surratt, J. D., and Stone, E. A.: Aromatic organosulfates in atmospheric aerosols: synthesis, characterization, and abundance, Atmos. Environ., 94, 366-373, 2014.

Stone, E. A., Yang, L., Yu, L. E., and Rupakheit, M.: Characterization of organosulfates in atmospheric aerosols at four Asian locations, Atmos. Environ., 47, 323-329, 2012.

Sun, Y. L., Zhang, Q., Anastasio, C., and Sun, J.: Insights into secondary organic aerosol formed via aqueous-phase reactions of phenolic compounds based on high resolution mass spectrometry, Atmos. Chem. Phys., 10, 4809-4822, doi:10.5194/acp-104809-2010, 2010.

Surratt, J. D., Gomez-Gonzalez, Y., Chan, A. W. H., Vermeylen, R., Shahgholi, M., Kleindienst, T. E., Edney, E. O., Offenberg, J. H., Lewandowski, M., Jaoui, M., Maenhaut, W., Claeys, M., Flagan, R. C., and Seinfeld, J. H.: Organosulfate formation in biogenic secondary organic aerosol, J. Phys. Chem. A, 112, 8345-8378, 2008.

Surratt, J. D., Kroll, J. H., Kleindienst, T. E., Edney, E. O., Claeys, M., Sorooshian, A., Ng, N. L., Offenberg, J. H., Lewandowski, M., Jaoui, M., Flagan, R. C., and Seinfeld, J. H.: Evidence of organosulfates in secondary organic aerosol, Environ. Sci. Technol., 41, 517-527, 2007.

Tao, S., Lu, X., Levac, N., Bateman, A. P., Nguyen, T. B., Bones, D. L., Nizkorodov, S. A., Laskin, J., Laskin, A., and Yang, X.: Molecular characterization of organosulfates in organic aerosols from Shanghai and Los Angeles Urban Areas by NanosprayDesorption Electrospray Ionization High-Resolution Mass Spectrometry, Environ. Sci. Technol., 48, 10993-11001, 2014.

Tolocka, M. P., Jang, M., Ginter, J. M., Cox, F. J., Kamens, R. M., and Johnston, M. V.: Formation of oligomers in secondary organic aerosol, Environ. Sci. Technol., 38, 1428-1434, 2004.

Tsimpidi, A. P., Karydis, V. A., Zavala, M., Lei, W., Molina, L., Ulbrich, I. M., Jimenez, J. L., and Pandis, S. N.: Evaluation of the volatility basis-set approach for the simulation of organic aerosol formation in the Mexico City metropolitan area, Atmos. Chem. Phys., 10, 525-546, doi:10.5194/acp-10-525-2010, 2010.

Tsimpidi, A. P., Karydis, V. A., Pozzer, A., Pandis, S. N., and Lelieveld, J.: ORACLE (v1.0): module to simulate the organic aerosol composition and evolution in the atmosphere, Geosci. Model Dev., 7, 3153-3172, doi:10.5194/gmd-7-31532014, 2014.

US EPA: Estimation Programs Interface Suite ${ }^{\mathrm{TM}}$ for Microsoft Windows v4.1, United States Environmental Protection Agency, Washington, DC, USA, 2015.

Wang, L., Khalizov, A. F., Zheng, J., Xu, W., Ma, Y., Lal, V., and Zhang, R.: Atmospheric nanoparticles formed from heterogeneous reactions of organics, Nat. Geosci., 3, 238-242, 2010.

Wania, F., Lei, Y. D., Wang, C., Abbatt, J. P. D., and Goss, K.-U.: Novel methods for predicting gas-particle partitioning during the formation of secondary organic aerosol, Atmos. Chem. Phys., 14, 13189-13204, doi:10.5194/acp-14-13189-2014, 2014.

Wania, F., Lei, Y. D., Wang, C., Abbatt, J. P. D., and Goss, K.-U.: Using the chemical equilibrium partitioning space to explore factors influencing the phase distribution of compounds involved in secondary organic aerosol formation, Atmos. Chem. Phys., 15, 3395-3412, doi:10.5194/acp-15-3395-2015, 2015.

Wei, Y. Y., Cao, T. T., and Thompson, J. E.: The chemical evolution $\&$ physical properties of organic aerosol: A molecular structure based approach, Atmos. Environ., 62, 199-207, 2012.

Weschler, C. J.: Chemistry in indoor environments: 20 years of research, Indoor Air, 21, 205-218, 2011.

Wildt, J., Mentel, T. F., Kiendler-Scharr, A., Hoffmann, T., Andres, S., Ehn, M., Kleist, E., Müsgen, P., Rohrer, F., Rudich, Y., Springer, M., Tillmann, R., and Wahner, A.: Suppression of new particle formation from monoterpene oxidation by $\mathrm{NO}_{\mathrm{x}}$, Atmos. Chem. Phys., 14, 2789-2804, doi:10.5194/acp-14-27892014, 2014.

Williams, B., Goldstein, A. H., Kreisberg, N. M., and Hering, S. V.: In situ measurements of gas/particle-phase transitions for atmospheric semivolatile organic compounds, P. Natl. Acad. Sci. USA, 107, 6676-6681, 2010.

Wisthaler, A. and Weschler, C. J.: Reactions of ozone with human skin lipids: Sources of carbonyls, dicarbonyls, and hydroxycarbonyls in indoor air, P. Natl. Acad. Sci. USA, 107, 6568-6575, 2010.

Zaveri, R. A., Easter, R. C., Shilling, J. E., and Seinfeld, J. H.: Modeling kinetic partitioning of secondary organic aerosol and size distribution dynamics: representing effects of volatility, phase state, and particle-phase reaction, Atmos. Chem. Phys., 14, 5153-5181, 2014.

Zhang, R., Khalizov, A., Wang, L., Hu, M., and Xu, W.: Nucleation and growth of nanoparticles in the atmosphere, Chem. Rev., 112, 1957-2011, 2011.

Zhang, R. Y., Wang, G. H., Guo, S., Zarnora, M. L., Ying, Q., Lin, Y., Wang, W. G., Hu, M., and Wang, Y.: Formation of urban fine particulate matter, Chem. Rev., 115, 3803-3855, 2015.

Zhang, X. and Seinfeld, J. H.: A functional group oxidation model (FGOM) for SOA formation and aging, Atmos. Chem. Phys., 13, 5907-5926, doi:10.5194/acp-13-5907-2013, 2013.

Zhao, Y., Hallar, A. G., and Mazzoleni, L. R.: Atmospheric organic matter in clouds: exact masses and molecular formula identification using ultrahigh-resolution FT-ICR mass spectrom- 
etry, Atmos. Chem. Phys., 13, 12343-12362, doi:10.5194/acp13-12343-2013, 2013.

Ziemann, P. J. and Atkinson, R.: Kinetics, products, and mechanisms of secondary organic aerosol formation, Chem. Soc. Rev., 19, 6582-6605, 2012.
Zuend, A. and Seinfeld, J. H.: Modeling the gas-particle partitioning of secondary organic aerosol: the importance of liquidliquid phase separation, Atmos. Chem. Phys., 12, 3857-3882, doi:10.5194/acp-12-3857-2012, 2012. 